G. B. Silberstein and C. W. Daniel, Science 237, 291 (1987); A. Lee and R. Langer, ibid. 221, 1185 (1983)

24. L. M. Sanders et al., J. Pharm. Sci. 73, 1294 (1984); F. G. Hutchinson and B. J. A. Furr, in Drug Carrier Systems, F. H. D. Roerdink and A. M. Kroon, Eds. (Wiley, New York, 1989), pp. 111-130.

25. A. M. Klibanov, Adv. Appl. Microbiol. 29, 1 (1983); D. B. Volkin and A. M. Klibanov, in Protein Function: A Practical Approach, T. E. Creighton, Ed. (IRL Press, Oxford, 1989), pp. 1-24.

26. R. Liu, R. Langer, A. M. Klibanov, Biotech. Bioeng., in press

27. M. J. Hageman, Drug. Dev. Ind. Pharm. 14, 2047 (1988).

28. B. Kari, Diabetes 35, 217 (1986); O. Siddiqui, Y. Sun, J. C. Liu, Y. W. Chien, J. Pharm. Sci. 76, 341 (1987)

29. B. R. Meyer et al., Clinical Pharmacol. Ther. 44, 607 (1988).

30. D. Levy, J. Kost, Y. Meshulam, R. Langer, J. Clin. Invest. 83, 2074 (1989).

31. H. Rosen, J. Chang, G. Wnek, R. Linhardt, R. Langer, Biomaterials 4, 131 (1983); K. W. Leong, B. C. Brott, R. Langer, Biomaterials 4, 131 (1983); J. Biomed. Mater. Res. 19, 941 (1985); A. Domb, C. Gallardo, R. Langer, Macromolecules 22, 3200 (1989).

32. K. W. Leong, P. D'Amore, M. Marletta, R. Langer, J. Biomed. Mater. Res. 20, 51 (1986); C. Laurencin et al., ibid., in press; H. Brem et al., Selective Cancer Ther. 5, 55 (1989); R. J. Tamargo, J. J. Epstein, C. S. Reinhard, M. Chasin, H. Brem, J. Biomed. Mater. Res. 23, 253 (1989).

33. H. Brem et al., J. Neurosurg., in press.

34. J. Heller, R. V. Sparer, G. M. Zenter, in Biodegradable Polymers as Drug Delivery Systems, M. Chasin and R. Langer, Eds. (Dekker, New York, 1990), pp. 121-161.

35. J. Kohn and R. Langer, J. Am. Chem. Soc. 109, 817 (1987); A. Staubli, E. Ron, R. Langer, ibid. 112, 4419 (1990).

36. I. Preis and R. Langer, J. Immunol. Methods 28, 193 (1979); S. Niemi, J. Fox, L. Brown, R. Langer, Lab. Anim. Sci. 35, 609 (1985).

37. J. Kohn et al., J. Immunol. Methods 95, 31 (1986).

38. E. Edelman, J. Kost, H. Bobeck, R. Langer, J. Biomed. Mater. Res. 19, 67 (1985)

39. J. Kost, K. Leong, R. Langer, Proc. Natl. Acad. Sci. U.S.A. 86, 7663 (1989).
40. J. Kost et al., J. Biomed. Mater. Res. 19, 1117 (1985).

41. F. F. Ghodsian, L. Brown, E. Mathiowitz, D. Brandenburg, R. Langer, Proc. Natl. Acad. Sci. U.S.A. 85, 2403 (1988)

42. M. Brownlee and A. Cerami, Science 206, 1190 (1979); S. W. Kim et al., J. Controlled Release 11, 193 (1990).

43. A. Heller, Acc. Chem. Res. 23, 128 (1990).

44. C. G. Pitt, Z.-W. Gu, R. W. Hendren, J. Thompson, M. C. Wani, J. Controlled Release 2, 363 (1985); J. Heller, ibid. 8, 111 (1988).

45. R. A. Siegel, M. Falmarzian, B. A. Firestone, B. C. Moxley, ibid., p. 179; L. Brannon-Peppas and N. A. Peppas, ibid., p. 267; E. Mathiowitz and M. D. Cohen, J. Membr. Sci. 40, 67 (1989); A. S. Hoffman, A. Afrassiabi, L. C. Dong, J. Controlled Release 4, 213 (1986); Y. H. Bae, T. Okano, R. Hsu, S. W. Kim, Makromol. Chem. Rapid Commun. 8, 481 (1987); P. E. Grimshaw, A. J. Grodzinsky, M. L. Yarmush, D. M. Yarmush, Chem. Eng. Sci. 44, 827 (1989).

46. R. Gurny, J. M. Meyer, N. A. Peppas, Biomaterials 5, 336 (1984); K. Park and J. R. Robinson, Int. J. Pharm. Amst. 19, 107 (1984).

47. B. B. Kahn, M. J. Charron, H. F. Lodish, S. V. Cushman, J. S. Flier, J. Clin. Invest. 84, 404 (1989); R. C. Kowal, J. Herz, J. L. Goldstein, V. Esser, M. S. Brown, Proc. Natl. Acad. Sci. U.S.A. 86, 5810 (1989).

48. J. Vacanti et al., J. Pediatr. Surg. 23, 3 (1988); F. Lim and A. M. Sun, Science 210, 908 (1980); P. Aebischer, S. R. Winn, P. M. Galletti, Brain Res. 448, 364 (1988); R. M. Dawson, R. L. Broughton, W. T. K. Stevenson, M. V. Sefton, Biomaterials 8, 360 (1987); S. Cohen et al., J. Am. Chem. Soc, in press.

49. J. M. Wilson et al., Science 244, 1344 (1989); J. R. Morgan, Y. Barrandon, H. Green, R. Mulligan, ibid. 237, 1476 (1987).

50. N. A. Peppas, in Controlled Drug Bioavailability, Drug Product Design and Performance, V. F. Smolen and L. A. Ball, Eds. (Wiley, New York, 1984), vol. 1, pp. 203-237; R. Langer and N. A. Peppas, J. Macromol. Sci. Rev. Macromol. Chem. 23, 61 (1983).

51. I thank H. Bernstein, S. Cohen, E. Edelman, A. Klibanov, and E. Tomlinson for their helpful reviews of this manuscript and J. Folkman for providing me with the inspiration to do research in this field. Supported by NIH grant GM 26698.

\title{
Molecular Targets for AIDS Therapy
}

\author{
Hiroaki Mitsuya, Robert Yarchoan, Samuel Broder
}

The development of antiretroviral therapy against acquired immunodeficiency syndrome (AIDS) has been an intense research effort since the discovery of the causative agent, human immunodeficiency virus (HIV). A large array of drugs and biologic substances can inhibit HIV replication in vitro. Nucleoside analogs-particularly those belonging to the dideoxynucleoside family-can inhibit reverse transcriptase after anabolic phosphorylation. 3'-Azido-2',3'-dideoxythymidine (AZT) was the first such drug tested in individuals with AIDS, and considerable knowledge of structure-activity relations has emerged for this class of drugs. However, virtually every step in the replication of HIV could serve as a target for a new therapeutic intervention. In the future, non-nucleoside-type drugs will likely become more important in the experimental therapy of AIDS, and antiretroviral therapy will exert major effects against the morbidity and mortality caused by HIV.
$\mathrm{H}$ UMAN IMMUNODEFICIENCY VIRUS (HIV) IS A PATHOgenic retrovirus and the causative agent of acquired immunodeficiency syndrome (AIDS) and its related disorders. One of the central questions after HIV was discovered was whether antiretroviral therapy would ever be feasible. Since that time, one drug, $3^{\prime}$-azido-2', $3^{\prime}$-dideoxythymidine (AZT or zidovudine) (1) has been shown to prolong the survival and improve the quality of life of individuals with advanced HIV infection $(2,3)$. More recently, the

The authors are at the National Cancer Institute, National Institutes of Health, Bethesda, MD 20892. administration of AZT was shown to delay clinical progression in certain asymptomatic individuals with HIV infection (4). Thus, the central question now is no longer whether antiretroviral therapy will be feasible, but rather, how to use the emerging knowledge of the viral life cycle to create new opportunities for therapy.

The purpose of this review is to discuss some principles for the development of antiretroviral drugs in the therapy of HIV infection and to highlight some recent advances in this area. Successful antiviral drugs, in theory, exert their effects by interacting with viral receptors, virally encoded enzymes, viral structural components, viral genes or their transcripts, or cellular factors required for viral 
replication (Table 1 ).

At present, no antiretroviral drug or agent is likely to be devoid of at least some toxicity or side effects. However, it is possible to make considerable clinical progress by carefully titrating the dose and schedule of various therapies to achieve antiviral activity while minimizing the risk of serious toxicities. The goal for future research is to find therapies that act on required processes for viral replication without affecting the physiology of normal cells. Available knowledge suggests that this goal is not beyond the reach of current technology.

The testing of agents for antiretroviral activity was facilitated by the availability of rapid and sensitive assay systems (5). A number of in vitro assay systems recently established should further accelerate the identification of new antiretroviral agents. Animal models for HIV infection, such as mice with genetically determined severe combined immunodeficiency that have been engrafted with human hematolymphoid cells from fetal liver, thymus, and lymph node (SCID-hu mice) (6), might also help expedite drug development.

\section{HIV, the Causative Agent of AIDS}

$\mathrm{HIV}$ is an enveloped single-stranded RNA virus, the genome of which exists as a dimer of identical RNA molecules. HIV has at least nine known genes (Fig. 1) and is the most complex retrovirus studied thus far. These nine genes are flanked at each end by sequences called long terminal repeats (LTRs) containing three regions, U5, R, and U3. The LTRs serve to initiate the expression of the viral genes, via complex processes requiring cellular RNA polymerase II as well as auxiliary transcription factors. The LTRs contain several characteristic regulatory elements: a sequence called the TATA box, which is indispensable for core promoter function (7); upstream enhancer regions, to which cellular transcription factors (for example, Spl and NF-kB) bind and activate HIV transcription $(8,9)$; a negative regulatory element (NRE) located at the $5^{\prime}$ end of U3 (10); a trans-acting responsive sequence (TAR) $(10,11)$; and a polyadenylation signal sequence $(7)$.

Before human pathogenic retroviruses were identified, retroviruses were known to contain a set of three genes-designated gag, pol, and env-as basic components of a replicating genome. HIV, in common with previously known animal retroviruses, has as its major structural components: a core of genomic RNA; gag-encoded proteins, which are important both in determining the structure of the core and in the assembly of the virion in the membrane of the host cell; a lipid bilayer; a transmembrane envelope glycoprotein (gp4l) spanning the lipid layer; and an outside envelope glycoprotein (gpl20).

The specific functions of several of the HIV genes shown in Fig. 1 are unclear, and more research is needed to determine if they could be the target of new therapies. It has been suggested that one such gene, $v p u$, functions in the assembly or maturation of progeny viruses, and thus facilitates virus release from infected cells (12). However, it is still not known whether this gene is essential for HIV replication. Another gene, vif (for virion infectivity protein), has been linked to the ability of HIV to replicate by a pathway of cellfree virion infection (13), although the exact function of vif also remains to be determined. Yet another gene, $v p r$ (for viral protein $\mathrm{R}$ ), is conserved in HIV-1 and HIV-2 (14). The vpr gene may be dispensable, at least in cultured lymphoid cells (15).

Three regulatory genes-tat, rev, and nef-and several important viral and cellular elements linked to HIV replication, such as TAR and NF- $\mathrm{BB}$, will be discussed later.

\section{Inhibition of Viral Entry}

Binding of HIV to target cells. The first molecule that HIV encounters as it begins infection of a target cell is the CD4 moleculealthough CD4 does not seem to be the only target molecule for HIV infection (16). In late 1987 and early 1988, several groups reported that recombinant truncated soluble CD4 could inhibit HIV binding and replication in $\mathrm{CD}^{+}{ }^{+}$target cells in vitro (17).

The use of soluble CD4 as a therapeutic approach against HIV infection is still evolving. Hybrid molecules have been created by genetically combining CD4 with the constant heavy chain domains of human (18) or murine (19) immunoglobulin (Ig). Human CD4Ig hybrid molecules are immunoadhesins, which retain an antiviral activity against HIV-1 comparable to that of soluble CD4 in T cells and monocytes and macrophages in vitro. Because of the presence of the Ig heavy chain domains, such immunoadhesins possess a longer plasma half-life, a capacity to cross the placenta, and a capacity to bind Fc receptors with high affinity (17). Under some conditions,

Table 1. Selected stages of HIV replication that may be targets for therapeutic intervention.

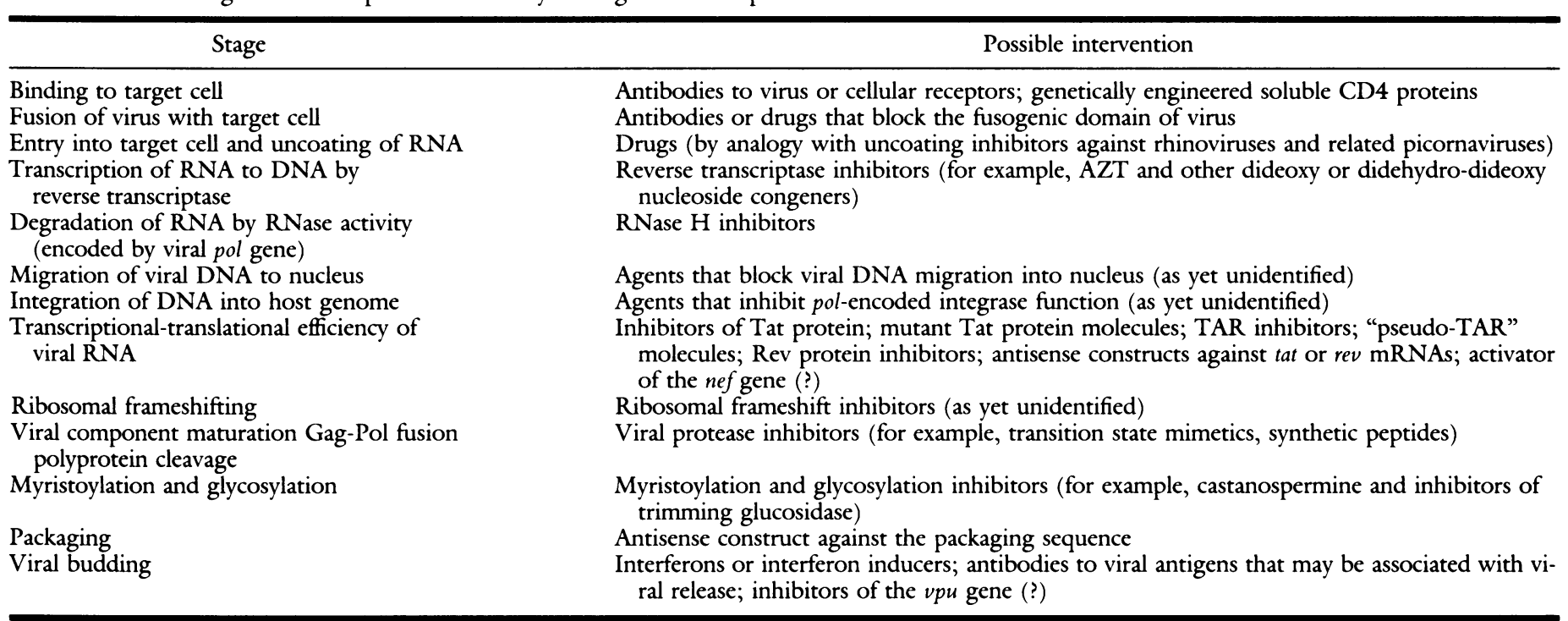



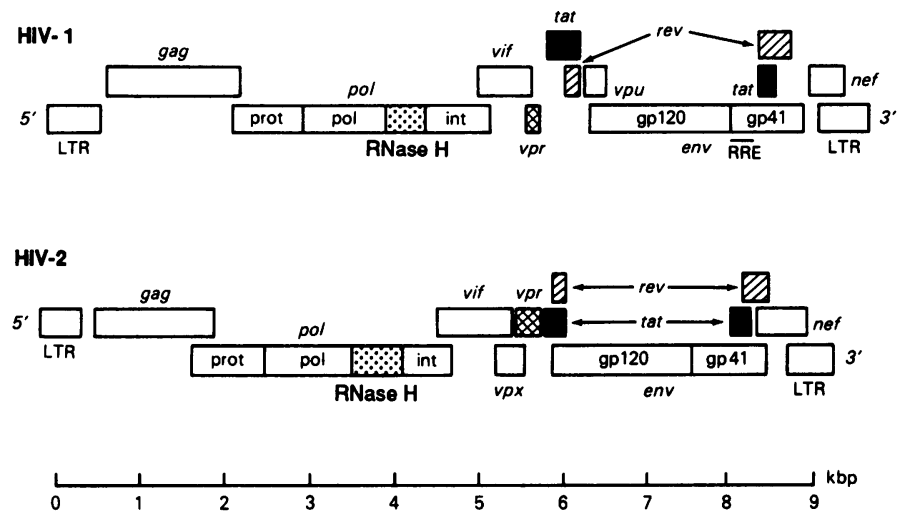

Fig. 1. Genetic organization of HIV-1 and HIV-2. The three levels in each panel represent the three different reading frames in which the genes are located. LTR, long terminal repeat; gag, group-specific antigen gene; pol, gene encoding the reverse transcriptase (pol) with associated RNase $\mathrm{H}$ activity, the protease (prot), and the integrase (or endonuclease) (int); vif, viral infectivity factor gene; $v p r$, viral protein $\mathrm{R}$ gene; $v p u$, viral protein $\mathrm{U}$ gene; env, envelope glycoprotein gene, encoding gpl20 and gp4l; tat, transactivating protein gene; rev, gene encoding the regulator of expression of virion proteins; nef, negative regulator factor gene; $v p x$, viral protein $\mathrm{X}$ gene. Within the LTR are three regions, U5, R, and U3 (not shown). Polyadenylation occurs in the $\mathrm{R}$ region of the $3^{\prime}$ LTR. The rev-responsive element (RRE) is indicated. TAR (trans-acting responsive element) is located between nucleotides +1 and +42 in the $5^{\prime}$ LTR (11). The scale is on kilobase pairs (kbp)

they mediate antibody-dependent cell-mediated cytotoxicity. It is not yet clear to what extent the addition of Ig components to CD4 can provide advantages in a clinical setting.

Soluble CD4 (20) or monoclonal antibodies specific for the viral envelope glycoprotein (21) can be conjugated to toxins, such as Pseudomonas exotoxin, ricin, or a radionuclide. Thus, in theory, one could specifically destroy and eliminate chronically HIV-infected cells, although, thus far, this approach has been studied only in vitro.

A potential advantage for the use of soluble CD4 as a therapeutic agent is that this strategy could inhibit diverse HIV isolates. However, HIV-2 viruses (which are related to simian immunodeficiency virus) are less susceptible to the inhibitory effects of soluble CD4 than HIV-l viruses $(16,22)$. A higher density of envelope glycoprotein in HIV-2 isolates may explain, at least in part, this resistance (22). Furthermore, many primary HIV-l isolates from individuals with AIDS are relatively insensitive to soluble CD4 in

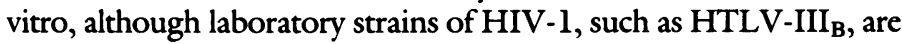
highly sensitive (23). Such primary HIV-l isolates were also relatively insensitive to CD4-Ig hybrid molecules in vitro. These findings may pose a challenge for soluble CD4-based antiretroviral therapy. In a recently completed phase I/II clinical trial, a decline in serum HIV-1 p24 antigen was observed in individuals receiving 30 mg of soluble CD4 per day (24). In two other trials, however, individuals receiving up to $300 \mu \mathrm{g}$ of soluble CD4 per kilogram of body weight showed no constant or substantial changes in $\mathrm{CD}^{+} \mathrm{T}$ cell numbers or p24 antigen concentrations in serum (25). It is likely that higher than originally anticipated concentrations of soluble CD4 may need to be achieved for antiviral effects in vivo.

Low molecular mass dextran sulfate (7,000 to 8,000 daltons) has been shown to block the binding of HIV virions to $\mathrm{CD}^{+}$target cells, to inhibit virally induced syncytium formation, and to exert a potent inhibitory effect against HIV in vitro (26). A phase $\mathrm{I} / \mathrm{II}$ trial of orally administered dextran sulfate suggested that this compound had little toxicity but also little proven clinical effect (27). Subsequent studies showed that dextran sulfate was very poorly absorbed when given orally, with changes in partial thromboplastin time being used as a marker (28). More recent data in the rat have suggested that this anionic polysaccharide is almost totally degraded when given orally, and sufficient inhibitory concentrations are not achieved in plasma (29). Perhaps dextran sulfate could be viewed as a prototype for research on a large class of anionic polysaccharides of both natural and synthetic origin [for example, pentosan sulfate (30)] that can block viral replication by inhibiting viral binding or other early events.

Later stages in the process of viral entry are also potential targets for AIDS therapy, although these later stages are less thoroughly understood. According to one plausible model (31), the binding of gpl20 to cellular CD4 induces a change in the conformation of the envelope, unmasking a specific site-called the fusogenic domainin the hydrophobic gp4l transmembrane portion of the viral envelope. This hydrophobic site of gp4l is thought to be normally hidden under the gp120 molecule. Once it is unmasked, the hydrophobic domain interacts with the adjacent cell membrane and induces virion-cell or cell-cell fusion. Antibodies or drugs that interfere with these fusogenic domain functions could theoretically block HIV replication.

Uncoating and functional release of HIV RNA. After HIV enters the cell, the virus is thought to lose the envelope coat and release its functional RNA genome into the cytoplasm as a ribonucleoprotein complex-a process known as uncoating. Therapeutic strategies to block uncoating or freeze the retrovirus in its nucleocapsid state, and thereby functionally prevent RNA release, would be worth pursuing in the setting of HIV infection. In fact, several uncoating inhibitors, such as arildone and WIN51711, have been shown to inhibit rhinoviruses and related picornaviruses (32).

The aromatic polycyclic dione compounds hypericin and pseudohypericin are active against HIV-1 in vitro (33). These compounds appear to confer abnormally high stability on the viral capsid structure. The resulting capsid rigidity may inhibit the process of uncoating or disassembly after penetration of HIV into the cell. A phase I clinical trial is now planned (33).

\section{Reverse Transcriptase: A Pivotal Target for Antiretroviral Therapy}

After viral entry and uncoating, viral RNA is used as a template for proviral DNA synthesis catalyzed by the viral DNA polymerase called reverse transcriptase-this enzyme is a component of the virion and is encoded by the pol gene. Reverse transcriptase has proven to be a successful target for the development of antiretroviral agents $(1,2,34-37)$.

As with other retroviruses, the reverse transcriptase is manufactured in HIV-infected cells as a Gag-Pol fusion polyprotein. The Gag and Pol proteins are encoded in two different translation reading frames, and protein synthesis depends on ribosomal frameshifting (38). In an animal retroviral model, the frameshifting reaction is mediated by slippage of two adjacent $t R N A s$ by a single nucleotide in the $5^{\prime}$ direction. Further definition of the frameshifting mechanism could lead to the development of new types of antiretroviral agents. The Gag-Pol fusion polyprotein undergoes post-translational cleavage mediated by the viral protease, also encoded by the pol gene (Fig. 1).

The mature HIV reverse transcriptase is a heterodimer, with subunit molecular masses of 51,000 and 66,000 daltons (39). The larger peptide (p66) contains a $\mathrm{COOH}$-terminal sequence (approximately 15,000 daltons) that has a ribonuclease $H(R N a s e ~ H)$ active site. RNase $H$ specifically degrades the RNA template of an RNADNA hybrid to permit synthesis of a double-stranded viral DNA. 
The synthesis of the second DNA strand is also catalyzed by the viral reverse transcriptase. In theory, inhibition of the RNase $\mathrm{H}$ activity should suppress viral replication, because an effective and orderly degradation of the template viral RNA is required for effective conversion of genomic RNA to proviral DNA. Although several potent $\mathrm{RNase} H$ inhibitors, such as vanadyl sulfate or polyguanylic acid, are known, cellular toxicity is a significant issue with some of these agents.

The HIV-1 reverse transcriptase is highly error-prone with a predicted error rate of five to ten per HIV-1 genome per round of replication in vivo (40). This high error rate is responsible for the extreme hypermutability of HIV, which is sometimes referred to as a "quasispecies (extreme heterogeneity)" (41). Thus, from a clinical point of view, the emergence of drug-resistant HIV variants must always be considered in relation to virtually any therapy.

\section{Migration and Integration of the Proviral DNA}

After synthesis of double-stranded DNA, the viral DNA can migrate into the nucleus by an as yet poorly characterized mechanism. Some proviral DNA may be circularized, although circularization apparently plays no role in integration (42). Several groups have reported details on the biochemical steps of retroviral integration for murine leukemia virus. In particular, a highly efficient cell-free system has been developed in which linear viral DNA molecules present in cytoplasmic extracts can integrate into heterologous DNA targets in vitro (43). Such a cell-free system may prove useful for the identification of agents that specifically inhibit the process of integration.

\section{Transcription and Translation}

After integration of the HIV genome into the host cell genome and a variable latency period-which is dependent on activation of the infected cell by physiological signals such as antigens (44) or regulatory cytokines (45)-the proviral DNA is transcribed to mRNA (viral genomic RNA) by host RNA polymerases. The cellular factor NF- $\mathrm{kB}$ contributes to the activation of transcription from the HIV-1 LTR by binding to specific sites within the viral enhancer regions (9). The cellular transcription factor $\mathrm{Spl}$ also binds to sequences (GC boxes) upstream from the TATA box and then activates viral transcription (8). To date, several other factors have been reported to bind to the LTR of HIV-l (46). Conceivably, altered versions of such factors, or chemicals capable of binding to these regulatory sequences without activation of HIV, could be developed to block viral replication.

$\mathrm{N}$-Acetylcysteine (NAC), which replenishes intracellular glutathione concentrations, inhibits TPA (12-O-tetradecanoyl phorbol-13acetate)-stimulated replication of HIV in acutely infected cells (47). NAC can also inhibit cytokine-activation of HIV expression in vitro. Although the mechanism of the antiviral activity of NAC remains to be studied, intracellular thiol concentrations might affect key regulatory events in HIV replication.

Proteins encoded by a variety of DNA viruses-such as herpes simplex virus (HSV) type 1 , human herpes virus type 6 , adenovirus, cytomegalovirus (CMV), hepatitis $\mathrm{B}$ virus, and human $\mathrm{T}$ cell leukemia virus (HTLV) types I and II-are also known to activate expression of HIV (48). It is conceivable that coinfection between such viruses and $\mathrm{HIV}$ is an important event in some clinical settings. Therefore, inhibition of the infectious processes mediated by these viruses may also help suppress the replication of HIV.
Whatever the precise mechanisms of transcriptional initiation, viral mRNA is subsequently translated to form viral proteins, again by the biochemical apparatus of the host cell. Conceivably, it should be possible to reduce the amount of viral mRNA, and thus selectively suppress the synthesis of viral proteins. Ribozymes are RNA molecules that possess enzymatic self-cleaving activity (49). The cleavage reaction is catalytic and no energy source is required. Ribozymes possess unique secondary (and also perhaps tertiary) structures critical for their cleavage ability, and those of the "hammerhead" motif have been shown to precisely cleave HIV-1 sequences in a cell-free system. When human cells stably expressing a hammerhead ribozyme targeted to HIV gag transcripts were challenged with HIV-1, a substantial reduction in the amount of HIV-1 gag RNA was observed (50). Because ribozymes are not consumed during degradation of target RNA, strategies that introduce small amounts of ribozymes into cells may result in the destruction of significant quantities of viral RNA and thereby block viral replication.

GLQ223-which is a basic protein also known as trichosanthinpurified from root tubers has also been shown to be active against HIV-l in vitro. Its mechanism of action may be to decrease the amount of HIV-1 RNA relative to total cellular RNA (51). Studies are underway to define its clinical usefulness.

The tat gene. The tat gene contains two coding exons and produces a diffusible protein, which, through the LTR sequences of HIV, markedly enhances the expression of viral genes and amplifies the production of new infectious virions at transcriptional or posttranscriptional steps (52). The Tat protein is small ( 86 amino acids) and contains a cluster of positively charged amino acids. It appears to form a dimer by a process that is mediated by binding to cadmium or zinc (53). The Tat protein exerts its effects by interacting with the short nucleotide sequence designated TAR, which is located within the 5' LTR region of viral mRNA transcripts (10, 11). The Tat protein may bind directly to TAR RNA and potentiate transcriptional processes. Cellular RNA-binding proteins may also play important roles in mediating tat-dependent LTR activation (52). Thus, inhibitors that could block the binding or functions of the Tat protein might efficiently inhibit viral replication. If "pseudoTAR" molecules could be introduced into target cells, they might also block Tat function. The Tat protein is taken up by cells and may subsequently trans-activate the LTR to enhance the expression of the virus (54). Protein sequence encoded by the second coding exon of the tat gene may be important for the binding of the Tat protein to target cells (55). Thus, on the basis of this observation, a nonactive but competitive Tat protein analog could also conceivably be used as a drug.

The Tat protein could affect the pathogenesis of AIDS not only by affecting viral replication but also, theoretically, by influencing the development of $K_{i}$;osi's sarcoma (KS), a key complication of the immunodeficiency associated with HIV infection. The tat gene has been shown to induce KS-like lesions in male transgenic mice (56), which suggests a pathogenetic link between KS and HIV-1 infection. It has been recently shown that Tat protein released from HIV-1-infected or tat-transfected cells can specifically promote growth of KS cells (57). Recombinant Tat protein also has the same growth-promoting properties (57). Thus, humoral or genetic factors such as Tat protein may possibly be associated with the development of $\mathrm{KS}$ in humans. These findings may provide clues for the development of drugs for the specific treatment of KS.

The rev gene. The rev gene (formerly known as art or trs) also exists as two coding exons and poduces a small (116-amino acid) positively charged protein, which is thought to function as a second essential trans-acting factor in viral replication (58). The pattern of RNA splicing in HIV is rather complex for a retrovirus and involves 
double splicing to generate regulatory gene mRNAs (for example, those of tat and rev). Viral mRNA splicing is performed by cellular mechanisms but these are regulated by the rev gene product. In the absence of the rev gene or its associated cis-acting element-known as the rev-responsive element (RRE) or the cis antirepression sequence (CAR) - located within the env region of HIV-l (Fig. 1), gag- and env-encoded protein synthesis is severely diminished (58, 59). As with the counterpart gene of HTLV-I (called rex), the rev gene product is thought to promote the transport of the unspliced viral mRNA containing RRE from the nucleus to the cytoplasm (60). The rev gene product also appears to increase the stability of unspliced and singly spliced viral mRNA species containing RRE. In theory, a therapeutic agent that blocks rev gene function could prevent the formation of full-length genomic RNA in an infected cell.

The nef gene. HIV has an additional regulatory gene, designated nef (for negative regulatory factor), the product of which has been reported to function as a transcriptional silencer to down-regulate the expression of the viral genome (61). Such down-regulation could conceivably be mimicked by a drug. The nef gene is thought to confer on HIV the ability to be dormant in the genome of the host cell; however, differential effects of the nef gene product on HIV replication and the lack of any effect as a negative factor have also been observed (62).

Thus, the tat, rev, and nef regulatory genes may form a complex network of regulatory interactions. This picture will likely become even more complicated when the functions of other regulatory genes-such as vif, $v p u$, and $v p r$-are clarified in the future. However, the very complexity of HIV could make this virus more vulnerable to coordinated attacks by antiretroviral drugs at multiple stages in its life cycle.

Antiviral agents targeted to transcription and translation. An intriguing strategy for blocking the expression of retroviral genes involves the construction of negative strand (antisense) synthetic oligodeoxynucleotides, an approach that was first proposed and tested by Zamecnik and Stephenson (63). However, several factors have complicated this research area. First, unmodified oligodeoxynucleotides are subject to rapid hydrolysis by host nucleases. Second, certain chemically modified oligomers are nuclease-resistant but have poor solubility and require exceedingly high concentrations for biological effects in vitro.

A phosphorothioate analog of a 28-nucleotide homo-oligodeoxycytidine $\left(S-\mathrm{dC}_{28}\right)$ is a potent inhibitor of $\mathrm{HIV}-\mathrm{l}$ in vitro in a sequence-independent manner (64). $S$ - $\mathrm{dC}_{28}$ preferentially inhibits HIV reverse transcriptase activity (65) and syncytium formation between HIV-1-producing cells and $\mathrm{CD}^{+}$target cells (66). Phosphorothioate oligomers have also been shown to inhibit the activity of the DNA polymerase and replication of HSV-2 in vitro (67). More recently, we identified a phosphorothioate hetero-oligomer complementary to the initiation sequence of HIV-l rev, which exhibited a sequence-specific inhibitory effect on the production of virally encoded proteins in chronically HIV-1-infected H9 cells (68). This antisense oligomer also reduced the amount of the genomic viral mRNA transcript, with relative sparing of smaller HIV mRNA species (68). Phosphorothioate analogs of antisense oligodeoxynucleotides against rev and gag genes have recently been shown to inhibit viral replication in different in vitro systems (69).

Phosphate-methylated DNA has been reported to hybridize to natural DNA and RNA with good conformational accommodations (70); therefore, such modified oligodeoxynucleotides might also prove useful as therapeutic agents. Both antisense and sense phosphate-methylated DNA oligomers targeted to TAR and the primer binding site have been reported to inhibit viral infectivity in vitro (70), although further study is required.
Comparatively large unmodified oligodeoxynucleotides can be taken up by cells in a saturable, size-dependent manner that is compatible with receptor-mediated endocytosis, and an $80-\mathrm{kD}$ surface protein that may mediate the transport has been identified (71). Phosphorothioate oligomers are also taken up by cells in a dose-dependent fashion and, at least in some human cells, are concentrated in the nucleolus and perinuclear organelles (possibly the Golgi apparatus and mitochondria) (72). Further study of the oligodeoxynucleotide transport mechanisms may facilitate the design of more potent oligomers against HIV.

Thus, modified antisense oligodeoxynucleotides may yield important theoretical and clinical insights into the regulation of HIV infection and could lead to the development of a new class of drugs that can control HIV expression in already infected cells. One formidable obstacle to clinical development, however, relates to the cost and technical difficulty of scale-up synthesis for human use. These technical hurdles need to be overcome before a clinical trial is possible.

\section{Viral Maturation, Transport, and Packaging}

Viral protease. The late stages in the replication of HIV include crucial virus-specific secondary processing of certain viral proteins by an HIV-l protease. The Gag-Pol fusion polyprotein undergoes post-translational cleavage by the viral protease to form active Gag and Pol proteins. In addition to reverse transcriptase and integrasean endonuclease responsible for integrating the proviral DNA into the cellular genome- the pol gene also encodes the viral protease, a promising target for therapy of HIV infection (73).

The work of Wlodawer's laboratory has been especially informative regarding the structure of the HIV protease (74). The protein has a symmetrical structure of two subunits and has a structural homology to the family of microbial (eukaryotic) aspartyl proteases $(74,75)$. X-ray crystallographic analyses of HIV-1 protease at $2.7 \AA$ resolution have confirmed that this enzyme exists as a homodimer (76). The crystal form of the protease per se, however, may not be suitable for understanding HIV protease inhibitors. Studies of the enzyme complexed with substrate-derived inhibitors would provide more detailed information needed for inhibitor design. In this regard, the HIV-l protease has been cocrystallized with a substratebased inhibitor in an x-ray study at a resolution of $2.3 \AA$ (77). Despite the symmetrical nature of the unliganded enzyme, the asymmetric inhibitor existed in a single orientation and made extensive interactions at the interface between the two subunits of the homodimeric protein. Substantial conformational changes in the protease were identified upon inhibitor binding.

The HIV protease represents a crucial virus-specific target for new therapies. Such an approach is one way of inhibiting the production of mature, infectious virions in chronically HIV-infected cells. Recently, peptide analogs have been synthesized (78) based on the transition-state mimetic concept (79). Some of such peptide analogs can inhibit protease function in cultures of HIV-l-infected cells, and can thus inhibit HIV-1 replication or attenuate the infectivity of virions produced (78). Most recently, a series of peptide derivatives containing a hydroxyethylamine moiety (80) based on the same concept have been synthesized. Some peptide derivatives (Fig. 2) inhibit both HIV-1 and HIV-2 proteases, with little effect on the structurally related human aspartyl proteases, and they exert a potent and highly specific antiretroviral activity against HIV-l in the nanomolar concentration range in multiple cell systems. Although further definition of the structure and function of the HIV protease is important in order to obtain rationally designed virus-specific inhibitors, there are enough exciting data to proceed in the direction 


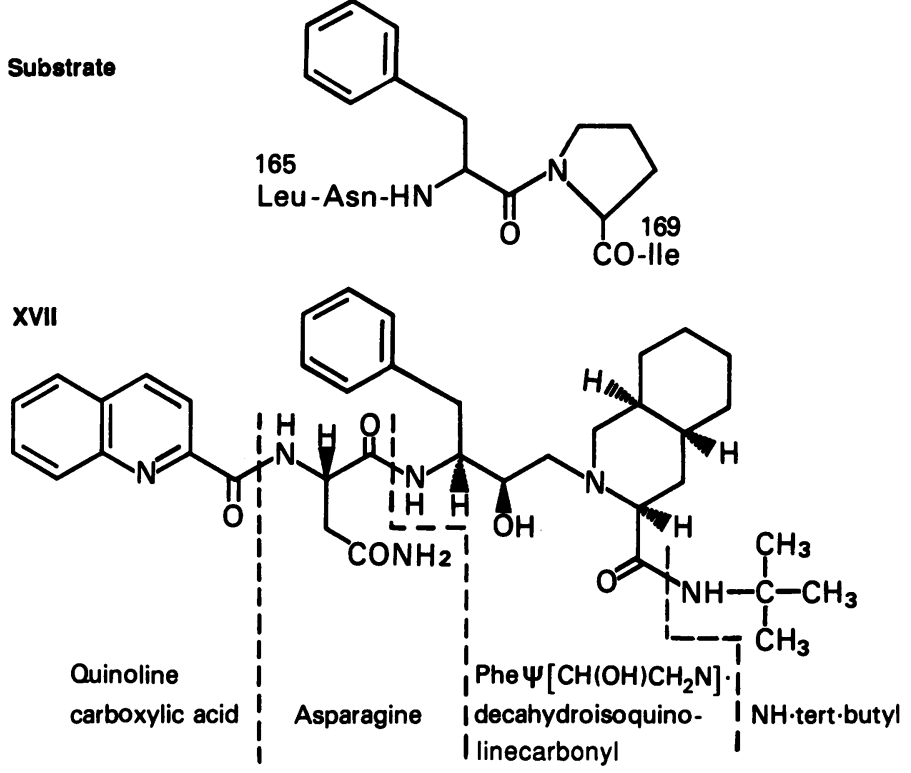

Fig. 2. Structures of the physiological substrate for the HIV protease and the transition state mimetic protease inhibitor XVII. The inhibitor contains the transition state moiety $\mathrm{Phe} \Psi\left[\mathrm{CH}(\mathrm{OH}) \mathrm{CH}_{2} \mathrm{~N}\right]$ decahydroisoquinolinecarbonyl in place of the $\mathrm{Phe}^{167}$-Pro ${ }^{168}$ scissile bond (79).

of clinical trials in which the protease is the target.

Glycosylation and myristoylation. In addition to the viral protease, cellular enzymes, such as glycosylating or myristoylating enzymes, also function in the maturation of viral components. Several trimming glycosidase inhibitors, including castanospermine and $\mathrm{N}$ butyldeoxynojirimycin, block HIV-induced syncytium formation and interfere with HIV infectivity in vitro (81). At this time, $N$ butyldeoxynojirimycin is the subject of a phase I clinical trial in the United States.

Cerulenin, an inhibitor of de novo fatty acid biosynthesis, inhibits the myristoylation and the proteolytic cleavage of the gag-encoded polyprotein (82). Monensin, a monovalent carboxylic ionophore, also blocks the proteolytic cleavage of precursor proteins, resulting in suppression of virus production (82). However, both compounds are highly toxic to cells in vitro, and their clinical application seems uncertain at this time.

Packaging signals for HIV RNA. A sequence called the $\Psi$ site is located between the tRNA primer binding site and the gag sequence in viral RNA. This region, apparently not encoding any protein, is thought to be responsible for the efficient packaging of genomic RNA into viral particles. The efficiency of an HIV-1 mutant with a deletion of 19 base pairs at the $\Psi$ site with regard to packaging virus-specific RNA into virions was less than 2 percent of that of the wild-type HIV (83). Viral particles produced by transfection of cells with such mutant HIV-1 were normal in protein content but were missing genomic RNA and were not infectious (84). This specific $\Psi$ sequence could also be a target for drugs or molecular strategies aimed at blocking the packaging process and thereby suppressing the production of infectious viruses.

\section{The Budding Process}

Finally, HIV virion particles are released by a process of viral budding, thus permitting the replicative cycle of HIV to start over again. Interferon- $\alpha$ (IFN- $\alpha)$ is thought to affect this budding process as well as several late events in the replicative cycle, and this agent is active against HIV in vitro during acute infection (85).
Studies of murine retroviruses indicate that interferons predominantly affect the late stages of virion release from the plasma membrane of chronically infected cells (86). Indeed, IFN- $\alpha$ suppresses the production or release of HIV virions in chronically infected cells, but has no effect on the amount of cell-associated viral proteins (87). One possible mechanism of the antiviral activity of IFN- $\alpha$ is that it alters the expression of one or more viral genes, such as $v p u$, required for the efficient assembly or release of progeny virions (87). Although the antiretroviral mechanism of interferons is as yet not clear, IFN- $\alpha$ may be clinically useful in several ways. This agent has an in vivo antitumor and antiretroviral effect in certain individuals with KS and AIDS (88). Significant in vitro synergistic antiviral activity of IFN- $\alpha$ against HIV has also been described when combined with other antiretroviral agents (89).

\section{2',3'-Dideoxynucleosides: A Broad Family of Antiretroviral Nucleosides}

A broad family of nucleosides with a $2^{\prime}, 3^{\prime}$-dideoxyribose moiety can inhibit the infectivity and replication of divergent HIV strains in vitro $(1,5,90)$. Three such agents have been administered to patients on a large scale in several countries. These $2^{\prime}, 3^{\prime}$-dideoxynucleosides were originally synthesized in the 1960s or earlier (91). Among them are AZT (Fig. 3, compound 1); 2', 3'-dideoxycytidine (ddC) (Fig. 3, compound 5); 2',3'-dideoxyadenosine (ddA) (Fig. 4, compound 1); $2^{\prime}, 3^{\prime}$-dideoxyinosine (ddI or didanosine) (Fig. 4, compound 2); and $2^{\prime}, 3^{\prime}$-dideoxyguanosine (ddG) (Fig. 4, compound 3). Initially, such agents were shown to block HIV replication in $\mathrm{T}$ cells $(1,5,90)$. It was subsequently demonstrated that dideoxynucleoside analogs including AZT could suppress the replication of HIV in monocytes and macrophages in vitro (92). During the past 5 years, a number of $2^{\prime}, 3^{\prime}$-dideoxynucleoside derivatives have been identified as being active against HIV, at least in vitro (93-98), and a great deal of knowledge in terms of structure-activity relations has emerged.

Structure-activity relations for $2^{\prime}, 3^{\prime}$-dideoxynucleoside analogs. The $2^{\prime}, 3^{\prime}$-dideoxynucleosides are of interest because they prove that a simple chemical modification in the sugar moiety can in some circumstances convert a normal substrate for nucleic acid synthesis into a potent inhibitor of the infectivity and replication of HIV. In appropriate target cells ( $\mathrm{T}$ cells, and monocytes and macrophages), the dideoxynucleoside analogs are sequentially phosphorylated in the cytoplasm to yield, ultimately, dideoxynucleoside $5^{\prime}$-triphosphates-although each drug may require a separate metabolic pathway $(5,37,90,99,100)$. They then become nucleotide analogs of the 2'-deoxynucleoside 5'-triphosphates, which are the natural substrates for cellular DNA polymerases and viral reverse transcriptase. These dideoxynucleoside 5 '-triphosphates can compete with normal 2'-deoxynucleotides for binding to reverse transcriptase or they can be incorporated into the growing DNA chain to bring about termination of viral DNA synthesis because a normal $5^{\prime} \rightarrow 3^{\prime}$ phosphodiester linkage cannot be completed $(5,37,90)$. In general, the various dideoxynucleosides are not equivalent in either activity or toxicity profiles in vitro or in vivo. For example, 2,6-diamino$2^{\prime}, 3^{\prime}$-dideoxypurine ribofuranoside has a potent antiretroviral activity in vitro; however, a very similar compound, 2 -amino- $2^{\prime}, 3^{\prime}$ dideoxypurine ribofuranoside (Fig. 4, compound 5), is not active in in vitro assays of antiretroviral activity (101). Therefore, each dideoxynucleoside must be considered to be a different drug in its own right. Even drugs that appear quite similar (for example, ddI and ddG) show significant differences in solubility, metabolic activation, and reversal of in vitro antiviral activity by normal nucleoside counterparts (5). 
Several 2 ', $3^{\prime}$-dideoxynucleoside 5 '-triphosphates have been extensively studied and have higher affinities for HIV reverse transcriptase than for cellular DNA polymerase $\alpha$, although cellular DNA polymerases $\beta$ and $\gamma$ (mitochondrial DNA polymerase) appear to be sensitive to the dideoxynucleoside- 5 '-triphosphates (102). The activity against mitochondrial DNA polymerase might explain certain side effects, such as a toxic mitochondrial myopathy in individuals receiving long-term AZT therapy (103).

$2^{\prime}, 3^{\prime}$-Dideoxythymidine (ddT) is not a particularly potent compound against HIV in our in vitro systems (90). The substitution of ddT with an $\alpha$-azido group at the $3^{\prime}$-carbon, however, produces erythro-AZT which is very potent against divergent strains of HIV in vitro (Fig. 3, compound 1) (1). AZT undergoes anabolic phosphorylation to generate AZT-5'-triphosphate (AZT-TP), which competes with thymidine $5^{\prime}$-triphosphate (104) and can function as a DNA-chain terminator. In this sense, AZT probably parallels the $2^{\prime}, 3^{\prime}$-dideoxynucleosides. It is, however, theoretically possible that AZT acts by an as yet unidentified intermediate.

Substitution of an atom at a certain position in a nucleoside analog can drastically change the antiviral activities of any given
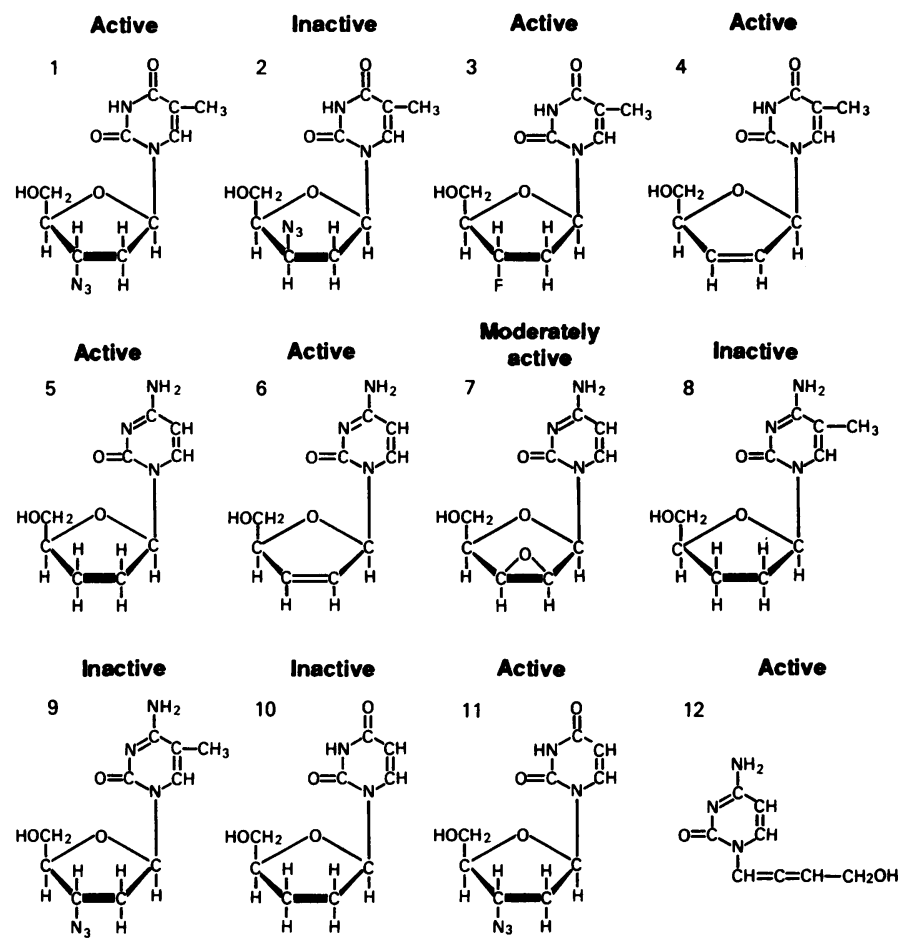

Fig. 3. Structures and in vitro antiretroviral activity of $2^{\prime}, 3^{\prime}$-dideoxypyrimidine nucleoside analogs. Antiretroviral activity of each compound was assessed under conditions of high multiplicities of infection with ATH8 cells, H9 cells, normal clonal CD4 ${ }^{+}$T cells, MT-2 cells or normal unfractionated peripheral blood mononuclear cells on the basis of inhibition of the cytopathic effect of HIV, suppression of gag protein production, or suppression of HIV viral DNA or RNA synthesis $(1,5)$. Compounds giving virtually a complete inhibition (80 to 100 percent) of the infectivity and cytopathic effect of HIV at concentrations that do not significantly affect the growth of target cells are defined as active. Compounds that inhibit the infectivity and replication of HIV by 30 to 80 percent are defined as moderately active. Compounds giving less than 30 percent inhibition are defined as inactive (136). $1,3^{\prime}$ - $\alpha$-azido- $2^{\prime}, 3^{\prime}$-dideoxythymidine (AZT or erythro-AZT); $2,3^{\prime}-\beta$-azido-2', $3^{\prime}$-dideoxythymidine (threo-AZT); $3,3^{\prime}$ - $\alpha$ fluoro-2', $3^{\prime}$-dideoxythymidine; $4,2^{\prime}, 3^{\prime}$-didehydro- $2^{\prime}, 3^{\prime}$-dideoxythymidine (2', $3^{\prime}$-dideoxythymidine or D4T); 5, 2', 3'-dideoxycytidine (ddC); 6, 2', $3^{\prime}$ didehydro- $2^{\prime}, 3^{\prime}$-dideoxycytidine $\left(2^{\prime}, 3^{\prime}\right.$-dideoxycytidinene or D4C); 7 , $2^{\prime}, 3^{\prime}$ - $\beta$-epoxy-2', $3^{\prime}$-dideoxycytidine; 8, 5-methyl-2', $3^{\prime}$-dideoxycytidine; 9, $3^{\prime}$-azido-5-methyl-2',3'-dideoxycytidine; 10, 2', $3^{\prime}$-dideoxyuridine (ddU); $11,3^{\prime}$-azido-2', $3^{\prime}$-dideoxyuridine (AZddU) (97); 12, 1-(4'-hydroxy-1', $2^{\prime}$ butadienyl)cytosine (cytallene).
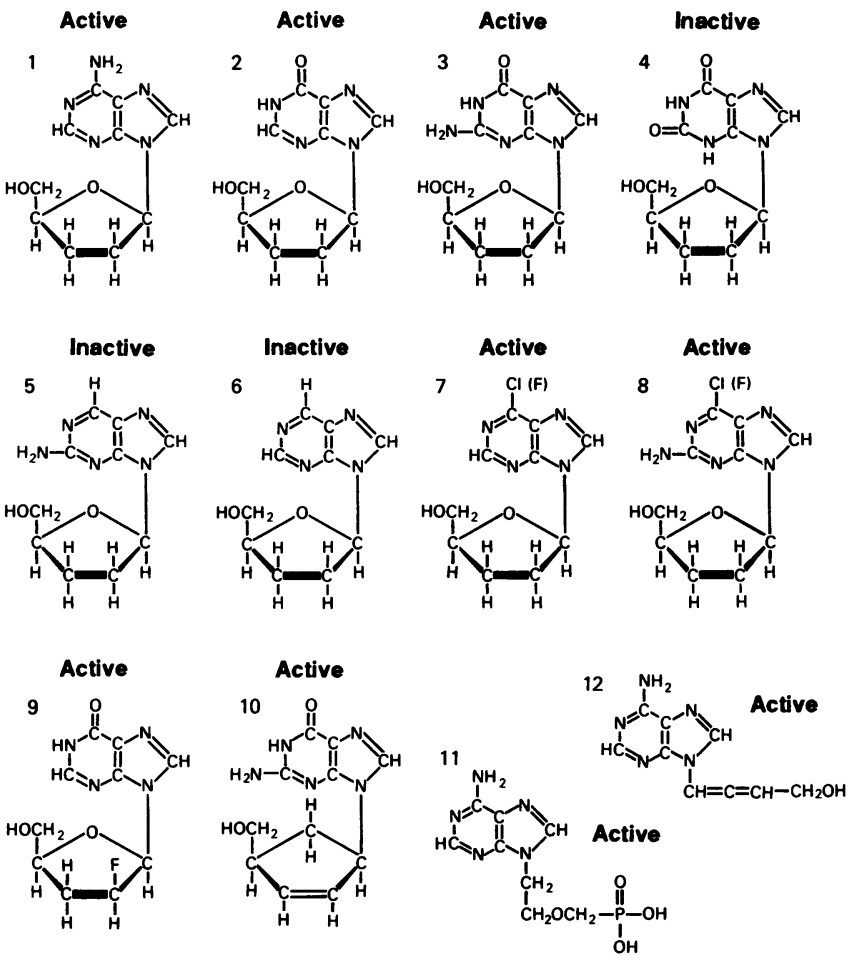

Fig. 4. Structures and in vitro antiretroviral activity of $2^{\prime}, 3^{\prime}$-dideoxypurine nucleoside analogs. Antiretroviral activity of each compound was assessed as described in the legend to Fig. 3 (136). 1, 2', $3^{\prime}$-dideoxyadenosine (ddA); 2, $2^{\prime}, 3^{\prime}$-dideoxyinosine (ddI); $3,2^{\prime}, 3^{\prime}$-dideoxyguanosine (ddG); 4, 2', $3^{\prime}$ dideoxyxanthosine; 5, 2-amino- $2^{\prime}, 3^{\prime}$-dideoxypurine ribofuranoside; 6 , 2',3'-dideoxypurine ribofuranoside; 7, 6-chloro (or 6-fluoro)-2', 3'-dideoxypurine ribofuranoside (105); 8, 2-amino-6-chloro (or 6-fluoro)-2', $3^{\prime}$-dideoxypurine ribofuranoside $(105) ; 9,2^{\prime}$ - $\beta$-fluoro- $2^{\prime}, 3^{\prime}$-dideoxyinosine; 10 , carbocyclic-2', 3'-didehydro-2', 3'-dideoxyguanosine (carbovir); 11, phosphonylmethoxyethyladenine (PMEA); 12, 9-(4'-hydroxy-1',2'-butadienyl)adenine (adenallene).

nucleoside. For instance, $\mathbf{3}^{\prime}$-azido substitution in ddC, generating $3^{\prime}$-azido-2', $\mathbf{3}^{\prime}$-dideoxycytidine (AZC), results in almost total loss of the in vitro antiretroviral activity (5). The $3^{\prime}$-azido substitution of ddA, generating $3^{\prime}$-azido-2' ${ }^{\prime}, 3^{\prime}$-dideoxyadenosine (AZA), enhances its toxicity and does not apparently affect the antiviral activity (5). On the other hand, the $3^{\prime}$-azido substitution in ddG, generating AZG, does not appear to alter its antiviral activity or cell toxicity (94). In many circumstances, a change in the stereochemistry of the substituent converts an active nucleoside to an inert compound. For example, a $\beta-3^{\prime}$-azido substitution of ddT, generating threo-AZT (Fig. 3, compound 2), completely abrogates the activity of ddT (101).

On a molar basis, ddC is one of the most potent dideoxynucleosides tested in susceptible $\mathrm{CD}_{4}^{+} \mathrm{T}$ cells-such as ATH8, H9, or normal CD4 ${ }^{+} \mathrm{T}$ cell clones-in vitro $(5,90)$. However, when the $\mathrm{ddC}$ molecule is substituted with a bromine or iodine substituent, or with a methyl group at the 5-position in the base, the antiviral activity is completely abolished (101). Also, when ddC is substituted both at the 5-position with a methyl group and at the 3'-position with an azide group, generating a "hybrid" nucleoside between ddC and AZT (Fig. 3, compound 9), no antiretroviral activity is evident in vitro (101).

The substitution of another atom for a hydrogen may confer in some cases a practical advantage to certain antiretroviral dideoxynucleosides. We have recently found that the substitution with a halogen atom at the 6-position of the base can increase the lipophilicity of dideoxypurine nucleosides without reducing their antiretroviral activity (Fig. 4, compounds 7 and 8) (105). These 6- 
halo compounds are metabolized by the ubiquitous enzyme adenosine deaminase to ddI or ddG in vitro (105). These compounds may represent a potential new class of lipophilic "pro-drugs" for ddI and ddG, and could show enhanced penetration of the blood-brain barrier. Both ddA and ddI are sensitive to low $\mathrm{pH}$ (solvolysis), and under acidic conditions they decompose to a base and a sugar moiety, resulting in a total loss of their antiretroviral activity (96). However, the substitution of a $\beta$-fluorine atom at the $2^{\prime}$-carbon, generating 2 '- $\beta$-fluoro- $2{ }^{\prime}, 3^{\prime}$-dideoxyadenosine or inosine congener (Fig. 4, compound 9), respectively, can result in acid stability, with retention of antiretroviral activity (96). $\alpha$-Fluorine substitution, generating an erythro-isomer of $2^{\prime}$-fluoro-ddA, also produces acid resistance. However, this latter substitution nullifies antiretroviral activity (96). This is a reminder that each drug must be evaluated in its own right, and there is still no reliable algorithm for predicting which congeners will exert more antiviral activity or less cellular toxicity.

\section{2',3'-Dideoxynucleosides as Therapeutic Agents for HIV Infection}

$A Z T$. In July 1985 , on the basis of the in vitro data described above, AZT was first administered to individuals with severe HIV infection at the National Cancer Institute and Duke University Medical Center (2). This initial study showed that individuals with AIDS and AIDS-related complex (ARC) underwent immunological, virological, and clinical improvement during the therapy with AZT. In particular, the study showed that AZT can increase the number of circulating $\mathrm{CD}^{+}{ }^{+} \mathrm{T}$ cells and the ratio of $\mathrm{CD}^{+}$to $\mathrm{CD}^{+}$ $\mathrm{T}$ cells. On the basis of these results, Wellcome Research Laboratories began a multicenter, randomized, placebo-controlled trial of AZT in February 1986.

The phase II clinical data on AZT confirmed the phase I data and demonstrated a reduced mortality in patients receiving AZT, thus ending the placebo-control arm in September 1986 (3). In March 1987, AZT was approved as a prescription drug for patients who have had episodes of Pneumocystis carinii pneumonia or whose CD4 ${ }^{+}$ cell count is below 200 cells per cubic millimeter. It has also been shown that AZT treatment improves or delays certain HIV-associated neurological symptoms in both adults and children with HIV infection $(2,35)$. However, bone marrow suppression was identified as a toxic side effect, requiring transfusions or a dose reduction in about a third of patients during the first 6 months of the trial (3). It is worth noting that for virtually any experimental agent, careful dose-seeking studies are required. It is common for the initial dose of new drugs to differ significantly from the final optimal dose. Although various attempts have been made to manipulate the nucleotide pools of cells in order to selectively reverse the myelotoxicity of AZT without loss of antiviral activity in vitro (106), the clinical usefulness of such approaches remains to be determined. In this regard, a recent result of a randomized, double-blind, placebocontrolled trial of recombinant erythropoietin in individuals with AIDS receiving AZT suggests that the majority of patients with anemia benefit from erythropoietin therapy (107). Other toxic effects of AZT include nausea, vomiting, myalgias, myopathy, seizures, headaches, liver function abnormalities, and bluish nail pigmentation $(2,3,37)$.

Recent data suggest that lower doses of AZT provide a benefit to certain subsets of patients, with significant reduction of toxicity or side effects (4). It is not clear as yet, however, whether the low dose of AZT will be adequate for children with HIV infection. This is because pediatric patients have a much higher clinical incidence of HIV-related central nervous system involvement, and it may be important to have higher concentrations of AZT in order to treat dementia that occurs in children (108). For these reasons, the Pediatric AIDS Clinical Trials Group is conducting a clinical trial in which a low dose of AZT $\left(90 \mathrm{mg} / \mathrm{m}^{2}\right.$ every 6 hours; similar to the dose recommended for adults) is compared to a higher dose (180 $\mathrm{mg} / \mathrm{m}^{2}$ every 6 hours) currently approved for children with symptomatic HIV infection.

Recently, it has been reported that AZT is tumorigenic in rodents (109). In standard lifetime carcinogenicity bioassay studies with rats and mice receiving high doses of AZT (initially $\geq 60 \mathrm{mg} / \mathrm{kg}$ per day and then $\geq 30 \mathrm{mg} / \mathrm{kg}$ per day) for approximately 22 months, seven vaginal tumors - five nonmetastasizing squamous cell carcinomas and two benign tumors-occurred in 60 female mice, and similar results were observed in rats. Although results from rodent carcinogenicity studies may or may not have predictive value for humans, further careful studies are required.

Soon after AIDS was recognized as a new clinical entity, clustering of high-grade non-Hodgkin's B cell lymphoma (NHL) in individuals with HIV-related diseases was noted (110). In some studies, approximately 3 percent of new AIDS cases had NHL as their AIDS-defining illness (111). It is possible that development of antiretroviral therapy may significantly affect such a clinical profile of HIV-related diseases per se. Pluda et al. from our group have recently reported that 46.4 percent ( 95 percent confidence interval of 19.6 to 75.5 percent) of individuals with fulminant AIDS or severe ARC may develop NHL after surviving for up to 3 years on AZT therapy (112). The mechanisms involved in the pathogenesis of AIDS-related NHL have not been elucidated. It is likely, however, that the pathogenesis of lymphoma in these settings relates to prolongation of survival in the face of chronically defective immunological functions. The occurrence of NHL in individuals with other forms of immunodeficiency, either primary or from immunosuppressive therapy, has been well documented (113). As improved therapies for the treatment of HIV and its complications result in prolonged survival, development of NHL and possibly other types of cancers may become an increasingly significant problem.

This observation should stimulate further research to find effective strategies for preventing, diagnosing, and treating the lymphomatous complications of HIV infection.

Emergence of $A Z T$-insensitive $H I V$ variants. The long-term administration of AZT has posed a new challenge. HIV strains have been isolated that are resistant to AZT in vitro (114). Such variants were most readily obtained from patients who had been receiving AZT therapy for more than 6 months. Comparative nucleotide sequence analysis of the reverse transcriptase coding region from five pairs of sensitive and resistant isolates revealed three amino acid substitutions common to all the resistant strains $\left(\mathrm{Asp}^{67} \rightarrow \mathrm{Asn}, \mathrm{Lys}^{70}\right.$ $\rightarrow$ Arg, and $\mathrm{Thr}^{215} \rightarrow$ Phe or Tyr) plus a fourth substitution in three isolates (Lys ${ }^{219} \rightarrow$ Gln) (115). Partially resistant isolates had combinations of these four changes. The mutations described would likely affect the charge or alpha helix content of the probable catalytic site for the reverse transcriptase. Research directed by Richman and his co-workers (116) is now focused on rapidly identifying such changes in HIV isolates from patients on AZT. Reverse transcriptase purified from these AZT-resistant HIV variants has shown no significant difference in sensitivity to AZT-TP $(116,117)$. In 1987 , it was reported that site-directed mutagenesis of reverse transcriptase could render the enzyme insensitive to AZT-TP (118). However, recombinant infectious viruses carrying the pol gene encoding such an AZT$\mathrm{TP}$-insensitive mutant reverse transcriptase paradoxically showed hypersensitivity to AZT when tested in culture (119).

The observations that reverse transcriptase preparations of AZTresistant HIV strains do not show a difference in the $\mathbf{5 0}$ percent inhibitory dose $\left(I D_{50}\right)$ or the relevant Michaelis $\left(K_{\mathrm{m}}\right)$ or inhibition 
$\left(K_{\mathrm{i}}\right)$ constants with respect to AZT-TP $(114,117)$ could suggest that tests with purified reverse transcriptase do not reflect in situ enzymatic activity or the real inhibition phenomena vis-a-vis the relevant ribonucleoprotein complex, or that an intermediate product of AZT causes the antiviral effect against HIV in the cell. The mutations described could affect the binding of such an unidentified intermediate.

These AZT-resistant HIV strains are not cross-resistant to certain antiretroviral agents including ddC, ddI, $2^{\prime}, 3^{\prime}$-didehydro- $2^{\prime}, 3^{\prime}$ dideoxythymidine (D4T) (Fig. 3, compound 4), and the phosphonoformate (foscarnet) analogs $(116,117)$. More intensive studies on this drug-resistance issue are needed. Study of drug-resistant viral strains should make it possible to identify new viral targets and to develop more effective therapeutic strategies.

$d d C$. ddC exerts a potent antiretroviral effect against HIV in vitro (90) after its internalization into cells, which is apparently mediated by the nucleoside carrier (99). It was the second dideoxynucleoside to be administered to HIV-infected individuals. Short-term phase I clinical trials of $\mathrm{ddC}$ showed it can suppress the replication of HIV in vivo (34). Toxic effects of ddC, defined in Phase I clinical trials particularly at high doses, included skin eruptions, aphthous oral ulcerations, fever, and malaise, most of which were transient. However, a painful sensory-motor peripheral neuropathy was the dose-limiting toxic effect. Because the toxicity profile of ddC was very different from that of AZT, a regimen alternating AZT for 1 week and ddC for 1 week was undertaken (34). Initial observations were that the individual toxicities of the drugs were reduced, and some patients showed clinical improvement. Since June 1990, ddC has been available to patients with AIDS and ARC who are intolerant to or have failed to respond to AZT or ddI through an open-label safety study (expanded access). The large phase II/III studies currently underway in the United States, in which a low dose of $\mathrm{ddC}$ alone or in combination with AZT is being used, should define the role of ddC in the treatment of HIV infection.

$d d I$. ddI and the closely related compound ddA were first identified in 1985 as equally potent inhibitors of HIV replication in vitro (90). ddI is the deamination product of ddA, and the antiretroviral activity of ddI was unexpected, particularly in view of the observation that hypoxanthine arabinoside, the deamination product of adenine arabinoside (ara- $\mathrm{A}$ ), is only about one-tenth as active as araA against $\mathrm{HSV}$ in vitro (120). At least in culture, ddI is less toxic than AZT or ddC, and its therapeutic index appears to be wider (90). The toxicity of ddI against hematopoietic precursor cells also seems to be much less than AZT or ddC in vitro (121).

Both ddI and ddA are similar to AZT (but unlike ddC) in that they apparently diffuse into the cell without active transport (99, 122). ddA can be directly phosphorylated to $2^{\prime}, 3^{\prime}$-dideoxyadenosine $5^{\prime}$-monophosphate (ddAMP) in the cytoplasm by both deoxycytidine kinase and adenosine kinase (99). However, most ddA is deaminated by adenosine deaminase to ddI, phosphorylated to $2^{\prime}, 3^{\prime}$-dideoxyinosine $5^{\prime}$-menophosphate (ddIMP) by cytosolic $5^{\prime}$ nucleotidase (100), and converted to ddAMP by adenylosuccinate synthetase-lyase $(99,100)$. The latter route appears to be the predominant pathway in human cells. Because the intracellular halflife of $2^{\prime}, 3^{\prime}$-dideoxyadenosine-5' -triphosphate (ddATP) is 12 to 24 hours (123), even if the plasma half-life of ddI is relatively short (about $35 \mathrm{~min}$ ), ddI may be administered with less frequent dosing schedules (for example, every 8 to 24 hours) (36) than AZT.

The antiretroviral activity of ddI and ddA is not reversed by any of the normal 2'-deoxynucleosides or by hypoxanthine, or by any combination of these $(5,101)$. This is not the case with AZT, ddC, and ddG, drugs whose antiretroviral effects are readily nullified (that is, HIV viruses are "rescued") by their corresponding normal 2'deoxynucleosides in vitro $(1,5,101)$. This difference is rather surprising and not yet fully explained. We have seen that $2^{\prime}$ deoxyguanosine $(\mathrm{dG})$ can suppress $2^{\prime}, 3^{\prime}$-dideoxyguanosine-5' -tri- $^{\prime}$ phosphate (ddGTP) formation in certain human $\mathrm{T}$ cells in vitro (124), and this is one likely basis by which dG can nullify the antiretroviral activity of ddG.

ddI was first administered to individuals with AIDS or ARC in an escalating-dose phase I study at the National Cancer Institute in July 1988. In view of its acid lability, ddI must be given with antacids. In this study, as well as two other phase I studies (36) and a phase I/II study in pediatric patients (125), individuals receiving ddI showed improvement in immunological function and evidence of a decrease in viral load. The most notable adverse effects were painful peripheral neuropathy and acute pancreatitis. The latter toxicity can be lethal in rare circumstances. However, doses up to $9.6 \mathrm{mg}$ per kilogram of body weight have been tolerated in some patients for approximately 2 years without toxicity (126).

Three large multicenter phase II trials of ddI, cosponsored by the AIDS Clinical Trials Group and Bristol-Myers Squibb, are now underway in the United States: the first comparing the clinical efficacy of AZT and ddI, the second testing the effect of AZT and ddI in patients who have been undergoing long-term AZT therapy, and the third comparing three different doses of ddI in patients who cannot tolerate AZT therapy. These controlled clinical trials are essential to determine the clinical usefulness of $\mathrm{ddI}$, and until they are completed it will not be possible to know whether ddI is safe and effective in patients with AIDS.

D4T. D4T, which is also a member of the dideoxynucleoside family and has been shown to be active against HIV in vitro (98), is now under phase I study in individuals with AIDS or ARC. D4T is interesting because AZT-insensitive HIV strains do not show crossresistance to this compound (116). Preliminary data have shown that the majority of patients on D4T have an early rise in peripheral $\mathrm{CD}^{+}$cells, a decrease in the serum concentration of $\mathrm{p} 24$, and an improvement in constitutional symptoms during short-term D4T administration (127). Although several side effects including peripheral neuropathy have been documented as a dose-limiting toxicity in the phase I study, this drug is active and is likely to have a good margin of safety. Further clinical testing should be a high priority.

\section{Other Agents in Preclinical and Clinical Development}

We have thus far focused on the use of dideoxynucleosides as antiretroviral agents against HIV; however, a number of nucleosides that do not have an oxacyclopentane (pentafuranosyl) sugar moiety have also been shown to be active against HIV in vitro. Carbocyclic nucleosides are analogs that have the oxygen of the oxacyclopentane substituted with a carbon atom and are thus refractory to cleavage by phosphorylases and hydrolases. Carbocyclic $2^{\prime}, 3^{\prime}$-didehydro$2^{\prime}, 3^{\prime}$-dideoxyguanosine (designated carbovir) (Fig. 4, compound 10 ) is active against HIV in vitro (128). The $5^{\prime}$-triphosphate version of this compound apparently has a highly specific inhibitory effect on HIV reverse transcriptase, with little effect on the cellular DNA synthetic enzymes (128).

Oxetanocin-A, which is also active against HIV in vitro (129), is an adenine nucleoside analog naturally synthesized by Bacillus megaterium. We have recently observed that two carbocyclic oxetanocin analogs, designated cyclobut- $A$ and cyclobut-G, block the infectivity and replication of HIV-1 and HIV-2 in vitro (130). Both compounds also showed in vitro activity against HSV-1 and HSV2, CMV, and varicella-zoster virus (130). Infection with CMV has been linked to the susceptibility to and enhanced expression of HIV (131) and appears to correlate with rapid progression of retinal 
damage in certain individuals with AIDS. In this regard, cyclobut-A and $-\mathrm{G}$, or combinations of anti-HIV agents and anti-CMV drugs, could be useful.

Several acyclic nucleosides that do not have a ring structure or sugar moiety are also active against HIV in vitro. Phosphonylmethoxyethyladenine (PMEA) is one such compound with broad spectrum activity in vitro against a number of DNA and RNA viruses including HIV (Fig. 4, compound 11) (132). PMEA is acid resistant and is as potent as ddI and ddA on a molar basis in several assay systems. However, its oral bioavailability appears to be low. We have also recently identified two additional antiretroviral acyclic nucleoside analogs, designated adenallene (Fig. 4, compound 12) and cytallene (Fig. 3, compound 12) (133).

A number of new types of non-nucleoside compounds have recently been reported to be active against HIV in vitro. Tetrahydro-imidazo[4,5,1,jk] [1,4]-benzodiazepin-2(1H)-one and -thione (TIBO) derivatives, which are unrelated to any other known antiviral agents, are among such compounds (134). These compounds are interesting because they possess unusual structures and inhibit the replication of HIV-1 but not HIV-2 or any other DNA or RNA viruses in vitro (134). An early phase I clinical trial is now underway.

\section{Combinations of Multiple Antiretroviral Drugs}

As discussed above, there are several drugs that have potential for the treatment of HIV infection. However, any of these drugs may have serious dose-limiting toxicities. A logical extension of current therapeutic approaches would be to use combinations of agents that have different antiretroviral mechanisms or have different metabolic pathways. Such combination therapy will likely enhance the efficacy or reduce the toxic effects of each drug and also could minimize or retard the emergence of drug-resistant HIV variants. Indeed, we and others have shown that various combinations of drugs $\left(2^{\prime}, 3^{\prime}\right.$ dideoxypyrimidine nucleosides plus $2^{\prime}, 3^{\prime}$-dideoxypurine nucleosides, and combinations of $2^{\prime}, 3^{\prime}$-dideoxynucleosides plus different types of drugs such as IFN- $\alpha$, soluble CD4, or PMEA) can produce synergistic or at least additive antiretroviral activity against HIV without a concomitant increase in toxicity in vitro $(5,89,135)$. We have recently found that the antiviral activity of AZT against HIV in monocytes and macrophages is also potentiated by granulocytemacrophage colony-stimulating factor (GM-CSF) in vitro (45). In this regard, the antiretroviral activity of another $3^{\prime}$-azido-substituted dideoxypyrimidine analog, $3^{\prime}$-azido-2', $3^{\prime}$-dideoxyuridine (AZddU) (Fig. 3, compound 11) (97), was also potentiated by this cytokine in vitro (45). AZddU has been reported to have a wider therapeutic ratio in vitro (97) than $\mathrm{AZT}$, and clinical tests are now underway.

\section{Conclusion}

Antiretroviral therapy is now a practical reality. It is possible to block HIV replication in vivo and to confer significant clinical benefits to patients in both early and advanced states of infection. The possibility of developing comparatively nontoxic therapeutic strategies with one antiretroviral agent or a combination of antiretroviral agents may make it possible to prolong survival greatly in the face of HIV infection. The armamentarium of antiretroviral agents is likely to grow in the future. It is probable that many steps in the replicative cycle of HIV can become targets for new antiretroviral therapy. For the immediate future, continued progress is likely with one or more dideoxynucleoside analogs, and in particular with refinements in AZT or related drugs now in use. However, in the future it seems certain that a number of non-nucleoside analogs affecting multiple steps in viral replication will be clinically available, and they will decrease our reliance on nucleoside inhibitors of reverse transcriptase. The use of viral protease inhibitors is an especially interesting strategy. Future progress in the field of antiretroviral therapy will depend on effective basic research coupled with strict adherence to the principles of controlled clinical trials.

\section{REFERENCES AND NOTES}

1. H. Mitsuya et al., Proc. Natl. Acad. Sci. U.S. A. 82, 7096 (1985).

2. R. Yarchoan et al., Lancet i, 575 (1986); R. Yarchoan et al., ibid. i, 132 (1987).

3. M. A. Fischl et al., N. Engl. J. Med. 317, 185 (1987); D. D. Richman et al., ibid., p. 192.

4. P. A. Volberding et al., ibid. 322, 941 (1990).

5. H. Mitsuya and S. Broder, Nature 325, 773 (1987); H. Mitsuya, M. Matsukura, S. Broder, in AIDS: Modem Concepts and Therapeutic Challenges, S. Broder, Ed. (Marcel-Dekker, New York, 1987), pp. 303-333.

6. J. M. McCune et al., Science 241, 1632 (1988); J. M. McCune et al., ibid. 247, 564 (1990); M. B. Gardner and P. A. Luciw, FASEB J. 3, 2593 (1989).

7. L. Ratner et al., Nature 313, 277 (1985).

8. K. A. Jones, J. T. Kadonaga, P. A. Luciw, R. Tjian, Science 232, 755 (1986).

9. G. Nabel and D. Baltimore, Nature 326, 711 (1987); G. J. Nabel, S. A. Rice, D. M. Knipe, D. Baltimore, Science 239, 1299 (1988).

10. C. A. Rosen, J. G. Sodroski, W. A. Haseltine, Cell 41, 813 (1985).

11. J. A. Garcia, D. Harrich, L. Pearson, R. Mitsuyasu, R. B. Gaynor, EMBO J. 7, 3143 (1988); M. J. Selby et al., Genes Dev. 3, 547 (1989).

12. E. F. Terwilliger, E. A. Cohen, Y. Lu, J. G. Sodroski, W. A. Haseltine. Proc. Natl. Acad. Sci. U.S. A. 86, 5163 (1989); K. Strebel et al., J. Virol. 63, 3784 (1989).

13. A. G. Fisher et al., Science 237, 888 (1987); K. Strebel et al., Nature 328, 728 (1987).

14. F. Wong-Staal et al., AIDS Res. Hum. Retrovinuses 3, 33 (1987).

15. D. Dedera, W. Hu, N. V. Heyden, L. Ratner, J. Virol. 63, 3205 (1989).

16. P. R. Clapham et al., Nature 337, 368 (1989); M. Tateno, F. Gonzalez-Scarano, J. A. Levy, Proc. Natl. Acad. Sci. U.S. A. 86, 4287 (1989).

17. D. H. Smith et al., Science 238, 1704 (1987); R. A. Fisher et al., Nature 331, 76 (1988); R. E. Hussey et al., ibid., p. 78; K. C. Deen et al., ibid., p. 82; A. Traunecker, W. Lüke, K. Karjalainen, ibid., p. 84.

18. D. J. Capon et al., Nature 337, 525 (1989); R. A. Byrn et al., ibid. 344, 667 (1990).

19. A. Traunecker, J. Schneider, H. Kiefer, K. Karjalainen, ibid. 339, 68 (1989).

20. V. K. Chaudhary et al., ibid. 335, 369 (1988); E. A. Berger et al., Proc. Natl. Acad. Sci. U.S. A. 86, 9539 (1989).

21. S. Matsushita et al., J. Virol. 62, 2107 (1988); S. Matsushita et al., AIDS Res. Hum. Retrovinuses 6, 193 (1990).

22. D. J. Looney et al., J. Acquired Immune Defic. Syndr. 3, 649 (1990).

23. E. S. Daar et al., Proc. Natl. Acad. Sci. U.S. A., in press.

24. R. T. Schooley et al., Ann. Intem. Med. 112, 247 (1990).

25. J. O. Kahn et al., ibid., p. 254; R. Yarchoan et al., Proceedings of the V Intermational Conference on AIDS, Montréal, 4-9 June 1989 (abstr.), p. 564.

26. R. Ueno and S. Kuno, Lancet i, 1379 (1987); M. Ito et al., Antiviral Res. 7, 361 (1987); H. Nakashima et al., Antimicrob. Agents Chemother. 31, 1524 (1987); H. Mitsuya et al., Science 240, 646 (1988); M. Baba et al., Proc. Natl. Acad. Sci. U.S.A. 85, 6132 (1988).

27. D. I. Abrams et al., Ann. Intem. Med. 110, 183 (1989).

28. K. Lorentsen et al., ibid. 111, 561 (1989).

29. N. R. Hartman, D. J. Johns, H. Mitsuya. AIDS Res. Hum. Retrovinuses 6, 805 (1990).

30. M. Baba et al., Antiviral Res. 9, 335 (1988); H. Mitsuya et al., in Mechanisms of Action and Therapeutic Applications of Biologicals in Cancer and Immune Deficiency Disorders, J. E. Groopman, D. W. Golde, C. H. Evans, Eds. (Liss, New York, 1989), pp. 331-341; L. Biesert et al., AIDS 2, 449 (1988).

31. T. J. Matthews and D. P. Bolognesi, Sci. Am. 259, 120 (1988).

32. T. J. Smith et al., Science 233, 1286 (1986).

33. G. Lavie et al., Proc. Natl. Acad. Sci. U.S. A. 86, 5963 (1989); D. Meruelo et al., unpublished data.

34. R. Yarchoan et al., Lancet i, 76 (1988); T. C. Merigan et al., Ann. Intem. Med. 110, 189 (1989).

35. P. A. Pizzo et al., N. Engl. J. Med. 319, 889 (1988).

36. R. Yarchoan et al., Science 245, 412 (1989); J. S. Lambert et al., N. Engl. J. Med. 322, 1333 (1990); T. P. Cooley et al., ibid., p. 1340; R. Yarchoan et al., Rev. Infect. Dis. 12, s522 (1990).

37. H. Mitsuya and S. Broder, in The Human Retroviruses, R. C. Gallo and G. Jay, Eds. (Academic Press, Orlando, FL, 1990); R. Yarchoan, H. Mitsuya, C. E. Meyer, S. Broder, N. Engl. J. Med. 321, 726 (1989).

38. T. Jacks and H. E. Varmus, Science 230, 1237 (1985); T. Jacks et al., Nature 331, 280 (1988); T. Jacks et al., Cell 55, 447 (1989).

39. F. D. M. Veronese et al., Science 231, 1289 (1986)

40. J. D. Roberts et al., ibid. 242, 1171 (1988); B. D. Preston et al., ibid., p. 1168.

41. M. Goodenow et al., J. Acquired Immune Defic. Syndr. 2, 344 (1989).

42. T. Fujiwara and K. Mizuuchi, Cell 54, 497 (1988); P. O. Brown, B. Bowerman, H. E. Varmus, J. M. Bishop, Proc. Natl. Acad. Sci. U.S. A. 86, 2525 (1989).

43. C. M. Farnet and W. A. Haseltine, Proc. Natl. Acad. Sci. U.S.A. 87, 4164 (1990). 44. D. Zagury et al., Science 231, 850 (1986).

45. C.-F. Perno et al., J. Exp. Med. 169, 933 (1989); T. Folks et al., Proc. Natl. Acad. 
Sci. U.S.A. 86, 2365 (1989); T. Matsuyama et al., AIDS Res. Hum. Retrovinuses 5 , 139 (1989); G. Poli et al., J. Exp. Med. 172, 151 (1990).

46. K. Kawakami, C. Schedereit, R. G. Roeder, Proc. Natl. Acad. Sci. U.S. A. 85 4700 (1988); M. J. Lenardo, A. Kuang, A. Gifford, D. Baltimore, ibid., p. 8825; T. Mackawa, H. Sakura, T. Sudo, S. Ishii, J. Biol. Chem. 264, 14591 (1989); B. R. Franza, Jr. et al., Nature 330, 391 (1987).

47. M. Roederer et al., Proc. Natl. Acad. Sci. U.S. A. 87, 4884 (1990)

48. D. F. Spandau and C. H. Lee, J. Virol. 62, 427 (1988); S. Z. Salahuddin et al., Science 234, 596 (1986); P. R. Skolnik, B. R. Kosloff, M. S. Hirsch, J. Infect. Dis. 157, 508 (1988); J. D. Mosca et al., Nature 325, 67 (1987); P. Lusso et al., ibid. 337, 370 (1989)

49. T. R. Cech and B. Bass, Annu. Rev. Biochem. 55, 599 (1989).

50. P. S. Chang et al., Clin. Biotechnol. 2, 23 (1990); N. Sarver et al., Science 247, 1222 (1990).

51. M. S. McGrath et al., Proc. Natl. Acad. Sci. U.S. A. 86, 2844 (1989).

52. J. Sodroski et al., Science 227, 171 (1985); B. R. Cullen, Cell 46, 973 (1986); C A. Rosen and G. N. Pavlakis, AIDS Lond. 4, 499 (1990); G. N. Pavlakis and B. K. Felber, New Biologist 2, 20 (1990); C. I. Dingwall et al., Proc. Natl. Acad. Sci. U.S.A. 86, 6925 (1989); A. Gatignol et al., ibid., p. 7828.

53. A. D. Frankel, D. S. Bredt, C. O. Pabo, Science 240, 70 (1988); Proc. Natl. Acad. Sci. U.S. A. 85, 6297 (1988)

54. A. D. Frankel and C. O. Pabo, Cell 55, 1189 (1988); M. Green and P. M. Loewenstein, ibid., p. 1179.

55. F. Wong-Staal et al., unpublished data.

56. J. Vogel et al., Nature 335, 606 (1988)

57. B. Ensoli et al., ibid. 345, 84 (1990).

58. J. G. Sodroski et al., ibid. 321, 412 (1986); M. B. Feinberg et al., Cell 46, 807 (1986); D. D. Chang and P. A. Sharp, Science 249, 614 (1990).

59. C. A. Rosen, E. Terwilliger, A. Dayton, J. G. Sodroski, W. A. Haseltine, Proc Natl. Acad. Sci. U.S. A. 85, 2071 (1988); E. T. Dayton, D. M. Powell, A. I Dayton, Science 246, 1625 (1989); M. L. Zapp and M. R. Green, Nature 342, 714 (1989).

60. H. H. Siomi et al., Cell 55, 197 (1988); B. K. Felber, M. Hadzopoulou-Cladaras, C. Cladaras, T. Copeland, G. N. Pavlakis, Proc. Natl. Acad. Sci. U.S. A. 86, 1495 (1989); T. Nosaka et al., ibid., p. 9798. M. H. Malim, J. Hauber, S.-Y. Le, J. V. Maizel, B. R. Cullen, Nature 338, 254 (1989).

61. P. A. Luciw, C. Cheng-Meyer, J. A. Levy, Proc. Natl. Acad. Sci. U.S. A. 84, 1434 (1987); T. M. J. Niederman, B. Thielan, L. Ratner, ibid. 86, 1128 (1989)

62. C. Cheng-Mayer, P. Iannello, K. Shaw, P. A. Luciw, J. A. Levy, Science 246, 1629 (1989); S. R. Hammes, E. P. Dixon, M. H. Malim, B. R. Cullen, W. C Greene, Proc. Natl. Acad. Sci. U.S. A. 86, 9549 (1989); S. Kim, K. Ikeuchi, R. Byrn, J. Groopman, D. Baltimore, ibid., p. 9544.

63. P. C. Zamecnik and M. L. Stephenson, Proc. Natl. Acad. Sci. U.S. A. 75, 280 (1978); P. C. Zamecnik, J. Goodchild, Y. Taguchi, P. S. Sarin, ibid. 83, 4143 (1986)

64. M. Matsukura et al., Proc. Natl. Acad. Sci. U.S. A. 84, 7706 (1987)

65. C. Majumdar, C. A. Stein, J. S. Cohen, S. Broder, S. H. Wilson, Biochemistry 28 1340 (1989).

66. H. Mitsuya et al., Proceedings of the IV Intermational Conference on AIDS, Stockholm, 12-16 June 1988 (abstr.), p. 226

67. W.-Y. Gao, C. A. Stein, J. S. Cohen, G. E. Dutschman, Y.-C. Cheng, J. Biol. Chem. 264, 11521 (1989); W.-Y. Gao et al., Antimicrob. Agents Chemother. 34, 808 (1990).

68. M. Matsukura et al., Proc. Natl. Acad. Sci. U.S. A. 86, 4244 (1989).

69. S. Agrawal et al., ibid., p. 7790; K. Willard-Gallo et al., Proceedings of the VI Intemational Conference on AIDS, San Francisco, 20-24 June 1990 (abstr.), vol. 2, p. 171; G. Sczakiel and M. Pawlita, ibid., vol. 1, p. 181.

70. H. M. Buck et al., Science 248, 208 (1990).

71. S. L. Loke et al., Proc. Natl. Acad. Sci. U.S. A. 86, 3474 (1989); L. A. Yakubov et al., ibid., p. 6454.

72. G. Marti and W. Egan, unpublished data.

73. R. A. Kramer et al., Science 231, 1580 (1986); L. E. Henderson, T. D. Copeland R. C. Sowder, A. M. Schultz, S. Oroszlan, in Human Retrovinuses, Cancer and AIDS: Approaches to Prevention and Therapy (Liss, New York, 1988), pp. 135147.

74. A. Wlodawer et al., Science 245, 616 (1989); M. Miller, J. M. K. Jaskólski, M. Rao, J. Leis, A. Wlodawer, Nature 337, 576 (1989).

75. T. D. Meek et al., Proc. Natl. Acad. Sci. U.S. A. 86, 1841 (1989); M. A. Navia et al., Nature 337, 615 (1989); T. Blundell and L. Pearl, ibid., p. 596.

76. R. Lapatto et al., ibid. 342, 299 (1989).

77. M. Miller et al., Science 246, 1149 (1989)

78. T. D. Meek et al., Nature 343, 90 (1990); T. J. McQuade et al., Science 247, 454 (1990).

79. M. Szelke et al., Nature 299, 555 (1982).

80. N. A. Roberts et al., ibid. 248, 358 (1990).

81. I. Katoh, T. Yasunaga, Y. Ikawa, Y. Yoshinaka, ibid. 329, 654 (1987); R. A. Gruters et al., ibid., 330, 74 (1987); B. D. Walker et al., Proc. Natl. Acad. Sci. U.S.A. 84, 8120 (1987); A. Karpas et al., ibid. 85, 9229 (1988).

82. R. Pal, R. C. Gallo, M. G. Sarngadharan, ibid., p. 9283.

83. A. Lever, H. Gottlinger, W. Haseltine, J. Sodroski, J. Virol. 63, 4085 (1989)

84. A. Aldovini and R. A. Young, ibid. 64, 1920 (1990)

85. D. D. Ho et al., Lancet i, 602 (1985).

86. P. M. Pitha, N. A. Wivel, B. F. Fernie, H. P. Harper, J. Gen. Virol. 42, 467 (1979).

87. G. Poli, J. M. Orenstein, A. Kinter, T. M. Folks, A. S. Fauci, Science 244, 575 (1989).

88. J. E. Groopman et al., Ann. Intem. Med. 100, 671 (1984); J. A. Kovacs et al., ibid. $111,280(1989)$
89. K. L. Hartshorn et al., Antimicrob. Agents Chemother. 31, 168 (1987).

90. H. Mitsuya and S. Broder, Proc. Natl. Acad. Sci. U.S. A. 83, 1911 (1986); H. Mitsuya et al., ibid. 84, 2033 (1987); J. J. McGowan et al., Rev. Infect. Dis. 12, s513 (1990).

91. J. P. Horwitz, J. Chua, M. Noel, J. Org. Chem. 29, 2076 (1964); M. J. Robins and R. K. Robins, J. Am. Chem. Soc. 86, 3585 (1964); J. P. Horwitz, J. Chua, M. Nocl, J. T. Donatti, J. Org. Chem. 32,817 (1966); J. P. Horwitz, J. Chua, M. A. Da Rooge, M. Noel, I. L. Klundt, ibid. 31, 205 (1966); A. M. Doering, M. Jansen, S. S. Cohen, J. Bacteriol. 92, 565 (1966); W. Ostertag et al., Proc. Natl. Acad. Sci. U.S. A. 71, 4980 (1974); T. S. Lin and W. H. Prusoff, J. Med. Chem. 21, 109 (1978); K. Ono, M. Ogasawara, A. Matsukage, Biochem. Biophys. Res. Commun. 88, 1255 (1979); P. Furmanski, G. J. Bourguignon, C. S. Bolles, J. D. Corombos, M. R. Das, Cancer Lett. 8, 307 (1980); M. A. Waqar, M. J. Evans, K. F. Manly, R. G. Hughes, J. A. Huberman, J. Cell. Physiol. 121, 402 (1984).

92. C.-F. Perno et al., J. Exp. Med. 168, 1111 (1988).

93. J. Balzarini et al., Biochem. Biophys. Res. Commun. 140, 735 (1986); T. R. Webb, H. Mitsuya, S. Broder, J. Med. Chem. 31, 1475 (1988); J. Balzarini et al., Biochem. Pharmacol. 38, 869 (1989).

94. H. Hartmann, G. Hunsmann, F. Eckstein, Lancet i, 40 (1987); M. Baba, R. Pauwels, J. Balzarini, P. Herdewijn, E. De Clercq, Biochem. Biophys. Res. Commun. 145,1080 (1987).

95. C.-H. Kim, V. E. Marquez, S. Broder, H. Mitsuya, J. S. Driscoll, J. Med. Chem. 30, 862 (1987).

96. V. E. Marquez et al., Biochem. Pharmacol. 36, 2719 (1987); V. E. Marquez et al., J. Med. Chem. 33, 978 (1990).

97. R. F. Schinazi, C.-K. Chu, M.-K. Ahn, J. Clin. Biochem. Suppl. $11 D, 74$ (1987); B. F. H. Eriksson, C. K. Chu, R. F. Schinazi, Antimicrob. Agents Chemother. 33, 1729 (1989).

98. J. Balzarini et al., Mol. Pharmacol. 32, 162 (1987); Y. Hamamoto et al., Antimicrob. Agents Chemother. 31, 907 (1987).

99. D. A. Cooney et al., Biochem. Pharmacol. 35, 2065 (1986); G. Ahluwalia et al., ibid. 36, 3797 (1987).

100. M. A. Johnson et al., J. Biol. Chem. 263, 15354 (1988); M. A. Johnson and A. Fridland, Mol. Phamacol. 36, 291 (1989).

101. H. Mitsuya and S. Broder, unpublished data.

102. Y.-C. Cheng, G. E. Dutschman, K. F. Bastow, M. G. Sarngadharan, R. Y. C. Ting, J. Biol. Chem. 262, 2187 (1987); M. C. Starnes and Y.-C. Cheng, ibid., p. 988; M. A. Vazquez-Padua, M. C. Stranes, Y.-C. Cheng, Cancer Communic. 2, 55 (1990).

103. M. C. Dalakas et al., J. L. L. Griffin, N. Engl. J. Med. 322, 1098 (1990).

104. P. A. Furman et al., Proc. Natl. Acad. Sci. U.S. A. 83, 8333 (1986).

105. T. Shirasaka et al., ibid., in press.

106. J. P. Sommadossi, R. Carlisle, R. F. Schinazi, Z. Zhou, Antimicrob. Agents Chemother. 32, 997 (1988).

107. M. Fischl et al., N. Engl. J. Med. 322, 1488 (1990).

108. P. A. Pizzo, J. Infect. Dis. 161, 316 (1990)

109. Letter to physicians from Burroughs Wellcome Co., 5 Dec. 1989.

110. D. C. Doll and S. F. List, Lancet i, 1026 (1982); J. L. Ziegler et al., N. Engl. J. Med. 311, 565 (1984).

111. Centers for Disease Control, HIV/AIDS Surveillance Report, pp. 1-22 (1990).

112. J. M. Pluda et al., Ann. Intern. Med. 113, 276 (1990).

113. R. A. Gatti and R. A. Good, Cancer 28, 89 (1971); I. Penn, Adv. Cancer Res. 28, 31 (1978).

114. B. A. Larder, G. Darby, D. D. Richman, Science 243,1731 (1989).

115. B. A. Larder and S. D. Kemp, ibid. 246, 1155 (1989).

116. D. D. Richman, Rev. Infect. Dis. 12, s507 (1990); B. A. Larder, B. Cheseboro, D. D. Richman, Antimicrob. Agents Chemother. 34, 436 (1990); D. D. Richman, J. M. Grimes, S. W. Lagakos, J. Acquired Immune Defic. Synd. 3, 743 (1990).

117. T. Shirasaka et al., Proceedings of the VI Intemational Conference on AIDS, San Francisco, 20-24 June 1990 (abstr.), p. 185.

118. B. A. Larder, D. J. M. Purifoy, K. L. Powell, G. Darby, Nature 327, 716 (1987)

119. B. A. Larder, S. D. Kemp, D. J. M. Purifoy, Proc. Natl. Acad. Sci. U.S. A. 86, 4803 (1989).

120. F. A. Miller, G. J. Dixon, J. Ehrlich, B. J. Sloan, I. W. McLean, Jr., Antimicrob. Agents Chemother.-1968, 136 (1968).

121. J. M. Moliona and J. E. Groopman, N. Engl. J. Med. 321,1478 (1989); R. L. Fine et al., Proc. Am. Assoc. Cancer Res., Washington, DC, 23-26 May 1990, 31, 431 (abstr.) (1990).

122. T. P. Zimmerman, W. B. Mahony, K. L. Prus, J. Biol. Chem. 262, 5748 (1987).

123. G. Ahluwalia et al., ibid. 29, 349 (1988).

124. G. Ahluwalia, H. Mitsuya, S. Broder, D. John, unpublished data.

125. K. M. Butler et al., unpublished data.

126. R. Yarchoan et al., Lancet, ii, 526 (1990).

127. M. Browne, G. Curt, Brown University Phase I Working Group, unpublished data.

128. R. Vince et al., Biochem. Biophys. Res. Commun. 156, 1046 (1988); E. L. White et al., ibid. 161, 393 (1989).

129. H. Hoshino, N. Shimizu, N. Shimada, T. Takita, T. Takeuchi, J. Antibiot. 40, 1077 (1987).

130. S. Hayashi et al., Antimicrob. Agents Chemother. 34, 287 (1990); D. W. Norbeck et al. J. Med. Chem. 33, 1285 (1990)

131. J. A. Nelson, C. Reynolds-Kohler, M. B. A. Oldstone, C. A. Willey, Virology 165 , 286 (1988); J. A. McKeating, P. D. Griffiths, R. A. Weiss, Nature 343, 659 (1990).

132. R. Pauwels et al., Antimicrob. Agents Chemother. 32, 1025 (1988)

133. S. Hayashi et al., Proc. Natl. Acad. Sci. U.S. A. 8, 6127 (1988); S. Phadtare and J. Zemlicka, J. Am. Chem. Soc. 111,5925 (1989).

134. R. Pauwels et al., Nature 343, 470 (1990). 
135. M. Baba et al., Antimicrob. Agents Chemother. 31, 1613 (1987); V. A. Johnson et al., J. Infect. Dis. 159, 837 (1989); S. Hayashi et al., Antimicrob. Agents Chemother. 34, 82 (1990); V. A. Johnson, M. A. Barlow, D. P. Merrill, T. C. Chou, M. S. Hirsch. J. Infect. Dis. 161, 1059 (1990); M. W. Vogt et al., Science 235, 1376
(1987).

136. Unless shown otherwise, the in vitro antiviral activity of these compounds was determined by $\mathrm{H}$. Mitsuya and $\mathrm{S}$. Broder.

137. We thank T. Shimada and M. S. Reitz for critical reading of the manuscript.

\title{
Structural Characterization of a Partly Folded Apomyoglobin Intermediate
}

\author{
Frederick M. Hughson, Peter E. Wright, Robert L. Baldwin*
}

To understand why proteins adopt particular three-dimensional structures, it is important to elucidate the hierarchy of interactions that stabilize the native state. Proteins in partly folded states can be used to dissect protein organizational hierarchies. A partly folded apomyoglobin intermediate has now been characterized structurally by trapping slowly exchanging peptide $\mathbf{N H}$ protons and analyzing them by two-dimensional ${ }^{1} \mathrm{H}$ NMR (nuclear magnetic resonance). Protons in the $\mathrm{A}, \mathrm{G}$, and $H$ helix regions are protected from exchange, while protons in the B and E helix regions exchange freely. On the basis of these results and the three-dimensional structure of native myoglobin, a structural model is presented for the partly folded intermediate in which a compact subdomain retains structure while the remainder of the protein is essentially unfolded.

$\mathrm{T}$ HE FOLDING OF SMALL SINGLE-DOMAIN PROTEINS IS, IN most cases, highly cooperative. Stable, partly folded intermediates that might lend insight into the folding process are seldom observed. Intermediates are sometimes present transiently during folding, and techniques have been developed recently that probe their structures $(1,2)$. Such structural studies are technically demanding, and the existence of multiple unfolded forms adds to the difficulty of interpretation.

The failure to detect stable folding intermediates can be blamed on the stability of the native protein; conditions severe enough to unfold the native state usually destabilize partly folded states as well. Destabilizing the native state selectively, by removing a stabilizing ion or a prosthetic group or by site-directed mutagenesis, can promote the appearance of partly folded states. The best characterized example of a protein exhibiting such an "equilibrium" intermediate is $\alpha$-lactalbumin, which in the presence of a bound $\mathrm{Ca}^{2+}$

F. M. Hughson and R. L. Baldwin are in the Department of Biochemistry, Beckman Center, Stanford University School of Medicine, Stanford, CA 94305. P. E. Wright is in the Department of Molecular Biology, Research Institute of Scripps Clinic, 10666 North Torrey Pines Road, La Jolla, CA 92037.

*To whom correspondence should be addressed. unfolds cooperatively in a two-state reaction. When, however, the native state is destabilized by removal of the $\mathrm{Ca}^{2+}$, the protein begins to unfold at a lower denaturant concentration, revealing a partly folded state (3).

Myoglobin ( $\mathrm{Mb}$ ) has proved to be a tractable protein for structural studies of a stable intermediate. Removing the heme group destabilizes native $\mathrm{Mb}$ and leads to the appearance of a stable intermediate in low $\mathrm{pH}$-induced unfolding (4). At neutral $\mathrm{pH}$, apo$\mathrm{Mb}$ is compact with an $\alpha$-helix content of $\sim 55$ percent as measured by circular dichroism (CD). Although the detailed three-dimensional structure of apo-Mb is not known, we show here that it resembles holo-Mb by criteria based on amide proton exchange. Others have shown (4) that apo-Mb contains an ordered hydrophobic core, as judged by calorimetric criteria. As the $\mathrm{pH}$ is lowered below neutral, "native" apo-Mb unfolds in two distinct stages (Fig. 1): first to a compact intermediate with a helix content of $\sim 35$ percent, termed I, and then to a more fully denatured state with little residual helix. The intrinsic viscosity of apo- $\mathrm{Mb}$ at $\mathrm{pH} 2$ is large (4), as expected for a random-coil polypeptide chain.

The simple architecture of $\mathrm{Mb}$, consisting of eight $\alpha$ helices that assemble to form a hydrophobic pocket for the heme group, has guided thinking about plausible pathways for protein folding. For example, one model postulates that helices form early in folding and are stabilized by subsequent helix pairing reactions (5). The discovery of a stable intermediate in low $\mathrm{pH}$-induced unfolding offers the opportunity to study a partly folded state of apo-Mb in detail. Ultimately, however, kinetic experiments seem necessary to establish whether or not this intermediate lies on the folding pathway.

The apo-Mb I form tends to aggregate in solution (6). This property, although unsurprising because of the exposure of hydrophobic patches that might accompany partial unfolding, makes direct structure determination by $\mathrm{x}$-ray crystallography or NMR difficult. Therefore, we used an indirect method to gather detailed structural information about the compact intermediate. This method allows amide proton exchange rates to be measured at about 40 sites distributed throughout the protein. Because the exchange of amide protons for solvent protons can be strongly retarded by hydrogen-bonded secondary structure, measurement of exchange rates serves to map out regions of the protein that are folded. In the I form, the regions of apo-Mb corresponding to the $\mathrm{A}, \mathrm{G}$, and $\mathrm{H}$ helices contain many protected protons, whereas protons in the $\mathrm{B}$ and $\mathrm{E}$ helix regions exchange at rates near those expected for an 